1 Evaluating evidence from the Torridonian Supergroup (Scotland, UK) for Eukaryotic life on land in the 2 Proterozoic

3 A.T. Brasier ${ }^{1 *}$, T. Culwick ${ }^{2}$, L. Battison ${ }^{2}$, R.H.T. Callow ${ }^{2,3}$ \& M.D. Brasier ${ }^{2+}$

4 1: School of Geosciences, Meston Building, University of Aberdeen, Scotland, AB24 3UE

$5 \quad$ *corresponding author (a.brasier@abdn.ac.uk)

62 2: Department of Earth Sciences, Oxford University.

7 3: Statoil ASA, Svanholmen 8, Forus, Norway

$8+$ deceased

10 Abstract

11 The Stoer, Sleat and Torridon Groups lie unconformably on Palaeoproterozoic Lewisian metamorphic 12 rocks. They contain organic carbon microfossils claimed to be non-marine and to include eukaryotes. 13 Evidence for terrestrial interpretations from each Formation of the Torridonian Supergroup is first considered. The range of sedimentary structures, and the boron content of illite lead to an overall conclusion that, on present evidence, the Torridonian Supergroup was likely entirely non-marine. Evidence for terrestrial life in these rocks comes from microbially induced sedimentary structures (MISS) including wrinkle structures with reticulate and elephant-skin fabrics. Organic remains and microscopic carbonaceous compressions mostly reported from phosphates in the grey shales of the Stoer, Aultbea and Applecross formations are dominated by sphaeromorph acritarchs. The Diabaig phosphatic lagerstätte includes three-dimensional preservation of eukaryotic and prokaryotic organisms, providing remarkable insights into non-marine life around 1 billion years ago.

The Precambrian is no longer the fossil-barren 'Lost World' that intrigued Charles Darwin. Over the last several decades there have been significant advances in understanding of the evolving early marine biosphere (see for example Brasier et al., 2015). Questions remain, however, over the extent to which life had colonized terrestrial environments during the Proterozoic and early Palaeozoic. In 
recent years there has been a spate of high-profile work on the well-exposed Mesoproterozoic to Neoproterozoic 'Torridonian' sedimentary rocks of the Northwest Highlands of Scotland (Fig. 1; for example Parnell et al., 2010; Callow et al., 2011; Strother et al., 2011; Battison and Brasier, 2012; Wacey et al., 2014) that build on more than a century of geological mapping and sedimentology (Peach et al. 1907).

Precambrian organic carbon microfossils were first reported from the Torridonian rocks more than a hundred years ago (Teall 1907). Since then, Torridonian microfossils have been studied by several authors (Downie 1962; Cloud \& Germs 1971; Zhang 1982), but it is through the dual claims that the rocks hosting the microfossils are non-marine (Stewart 2002 and references therein) and eukaryotic (Strother et al. 2011) that Torridonian fossils have become the basis of our current understanding of the origin, evolution, resilience, impacts and preservation of life on Earth, particularly of the nonmarine realm.

Recent studies have had two broad aims: 1) to examine how the Torridonian microbiota fit within a global understanding of Proterozoic biological evolution (Wellman \& Strother 2015); and 2) to determine the environmental context in which these microfossils lived, died and were preserved (e.g. Parnell et al. 2010; Strother et al. 2011; Callow et al. 2011; Battison \& Brasier 2012; Brasier 2013; Wacey et al. 2014).

Here we critically examine what we really know about the Torridonian sedimentary rocks and the ancient environments they preserve. To do this means answering a series of questions:

1) what is the evidence that Torridonian terrestrial environments were inhabited? 2) what were the conditions that allowed the Torridonian organic-walled microfossils to be so well preserved? and 3) are we really sure the Torridonian sediments were deposited in rivers, alluvial fans and lakes?

Stratigraphy of the Torridonian Supergroup

The Torridonian Supergroup lies unconformably on Palaeoproterozoic Lewisian metamorphic rocks, and is comprised of the Stoer, Sleat, and Torridon groups (Stewart 2002; Fig. 2).

The Stoer Group consists of the Clachtoll, Bay of Stoer and Meall Dearg formations (Fig. 2), which are predominantly red mudstones, siltstones and sandstones. The Stac Fada Member of the Bay of Stoer 
Formation is interpreted as a meteorite ejector blanket marker horizon (Amor et al. 2008) and is radio-isotopically age dated at $1177 \pm 5 \mathrm{Ma}$ (Parnell et al. 2011). The Poll a'Mhuilt Member sandstones, shales and limestones of the Bay of Stoer Formation have been interpreted as having formed in a lacustrine environment (Stewart 2002).

The Torridon Group conglomerates, sandstones and mudstones are around 200 million years younger than the Stoer Group (Fig. 2). The Torridon Group is comprised of four formations. From oldest to youngest these are the Diabaig, Applecross, Aultbea, and Cailleach Head Formations. Phosphates in the Diabaig Formation are radio-isotopically dated at $994 \pm 48 \mathrm{Ma}$ (Turnbull et al. 1996).

The Sleat Group on the Isle of Skye has been considered more or less contemporaneous with the Torridon Group, but its correlation remains a topic of contention (Stewart 2002; Kinnaird et al. 2007; Spinks et al. 2014; Fig. 2).

Critical review of evidence for terrestrial environments

Underpinning the global importance of the Torridonian microbiota is the inference that the host rocks are entirely non-marine facies (Stewart \& Parker 1979; Stewart 1982, 2002). Here we examine the evidence for this for each formation, beginning with a purported palaeosol developed on Lewisian basement rocks (Retallack \& Mindszenty 1994).

Unconformity between the Torridonian sedimentary rocks and Lewisian basement

There is a pronounced unconformity between Lewisian basement rocks and the Torridonian sedimentary succession (Figs $2 \& 3$ ). In at least two places, Staca \& Sheigra, this surface has been considered to be demarcated by a palaeosol or at least a Precambrian weathered horizon (Williams 1966, 1968, 1969; Russell \& Allison1985; Retallack \& Mindszenty1994; Williams \& Schmidt1997; Stewart 2002; Williams 2015). Evidence for this comes from geochemistry along with petrographic features that could have developed during subaerial exposure in the Meso- to Neoproterozoic, and prior to onlap by the Torridonian Supergroup (Retallack \& Mindszenty1994). Several characteristics at Sheigra and Staca have been taken to support the inferred presence of a Precambrian soil at the local Archean - Proterozoic contact: 1) oxidation of iron in biotite and magnetite; 2 ) hydrolysis of plagioclase, orthoclase and hornblende; 3 ) slickensided planes of red clay interpreted as palaeosol 
clay skins, and smectite, which were interpreted to be syn-sedimentary because of the inferred paragenetic sequence in which they were cut by early diagenetic illite; 4) soil-like microfabrics, including carbonate nodules that have been inferred to be pedogenic (Retallack \& Mindszenty 1994). Organic carbon components from the Sheigra clay exhibited $\delta^{13} \mathrm{C}$ values around $-26 \%$ that might have reflected existence of terrestrial biota.

Evidence for purportedly pedogenic smectite has recently been challenged by the presence of thin veins of hydrothermal saddle dolomite within $1 \mathrm{~m}$ of the unconformity (Williams 2015). This implies hot fluids have been flowing along the contact, and these could have caused 'retrograde diagenesis' of illite and chlorite to form the mixed-layer illite-smectite and smectites previously interpreted as pedogenic. This could have happened either during the Silurian, in association with the Moine Thrust, or during Permian tectonism (Williams 2015), casting doubt on use ofgeochemical proxies for pedogenesis here. Dip-corrected stable palaeomagnetic directions obtained from haematite in the weathered horizon match with dip-corrected primary palaeomagnetic directions obtained from the Applecross and Aultbea Formations, implying that the haematite of the weathered surfaces formed at around the time that the sandstones of the Applecross and Aultbea formations were deposited (Williams \& Schmidt 1997). This could, however, have occurred through circulation of groundwaters in the shallow subsurface, and is not necessarily evidence of haematite formation within a soil.

Perhaps the most convincing evidence put forward for the existence of any subaerially exposed Precambrian land surface is the stratigraphy itself (Brasier 2014). It is beyond doubt that there is an unconformity cutting into Lewisian gneisses and amphibolites across the Northwest Highlands of Scotland (Stewart 2002), and there seems to be consensus amongst sedimentologists that the Applecross Formation is of fluvial origin (Williams 1966, 1968, 1969; Russell \& Allison 1985; Retallack \& Mindszenty 1994; Williams \& Schmidt 1997; Williams 2015). It is, therefore, a reasonable assumption that the top of the Lewisian complex at Sheigra and Staca was subaerially exposed, eroded and weathered prior to deposition of the overlying fluvial sediments However it would be somewhat circular to argue that all of the pre-Applecross Formation Torridonian sediments are terrestrial because they were deposited on eroded Lewisian bedrock that was later, during deposition of the Applecross Formation, demonstrably an exposed land surface. Reaching conclusions on terrestrial versus marine environments of these pre-Applecross, post-Lewisian rocks demands a more in-depth analysis of the sedimentology of the Torridonian succession. 
The Clachtoll Formation can be inferred to have been deposited on a terrain cut by valleys of considerable relief as noted by Peach et al (1907) and backed up by Stewart (2002 and references therein). In order to demonstrate the varied topography of the surface on which the Clachtoll Formation was deposited Stewart (2002) assumed that the Stac Fada Member of the Bay of Stoer Formation (Figs $2 \& 4$ ) was emplaced as a single temporal event that blanketed the terrain. This inference that the Stac Fada Member was deposited in a single event across the area seems well supported by its re-interpretation as a meteorite impact ejecta blanket (Amor et al. 2008). The Clachtoll Formation is distinguished from overlying units by the composition of its clasts, which are almost entirely derived from the Lewisian basement, and by its textural characteristics including grain size and sorting(Stewart 2002). At the base of some of the palaeo-valleys are conglomerates with sub-rounded clasts up to $50 \mathrm{~cm}$ in diameter that grade upwards into interbeds of conglomerate and red sandstone, locally with trough cross-bedding. These basal Torridonian red breccias and conglomerates are considered to be valley-confined alluvial fan deposits, based on a combination of sedimentary structures, and the inferred palaeo-topography (Stewart, 2002). Park et al. (2002) concur that these basal breccias and conglomerates were deposited in alluvial fans, and they deducted fan radii in the region of $300 \mathrm{~m}$. Muddy and desiccated sandstones of the Clachtoll Formation might have formed in a terrestrial mudflat environment (Park et al. 2002), while some conglomerates with trough cross-beds and erosional bases are likely of braided fluvial origin (Park et al. 2002), further supporting the sedimentological case that rocks at the base of the Torridonian Supergroup were deposited in a terrestrial setting.

Amor et al. (2008) studied the Stac Fada Member (Fig. 4) and noted the high proportion of melt clasts, fluidized flow inferred from shallow decline in unit thickness, basal shear zone, preferred horizontal clast orientations, and water inclusions in feldspars that were trapped at $200{ }^{\circ} \mathrm{C}$. From this they inferred the impactor hit volatile (groundwater)-rich sediments, and that the Stac Fada rocks were emplaced by a dense, turbulent, vapour-borne ground-flow. Branney and Brown (2011) deduced from the stratigraphy and sedimentology of the Stac Fada Member that it was probably deposited by a single density current. The capacity of the density current was "depletive", losing energy as it spread out radially from the impact site, and so depositing both as the flow waxed and waned. Some ash fallout from the atmosphere was deposited after the density flow. There seems no firm requirement in the Stac Fada Member sedimentology or geochemistry that the impactor hit a fully terrestrial site, although the assumption that the site was terrestrial was followed by Amor et al. (2008) and Branney and Brown (2011).. 
151 The Poll a' Mhuilt Member overlies the Stac Fada Member and consists of medium grained sandstones overlain by graded sandstones and siltstones (Fig. 5a), limestones (that are otherwise rare in the Torridonian), red and green siltstones, microfossil-bearing carbonaceous shales, grey planar laminated calcareous siltstones with pseudomorphs after gypsum (now composed of calcite, quartz and barite), and interbedded red shales and sandstones containing wave ripples (Fig. 5b) and desiccation cracks (Fig. 5c; Stewart 2002). Pseudomorphs after gypsum, small wavelength wave ripples, the boron content of illites, and presence of desiccation cracks are consistent with a playa lake interpretation of the The Poll a' Mhuilt Member (Picard \& High1972; Stewart \& Parker1979; Lundell \& Surdam 1995; Magee et al. 1995; Stewart 2002). Boron-in-illite values, regularly used as palaeo-salinity indicators in the 1960s and 1970s, provide some circumstantial supporting evidence of a lacustrine origin. This geochemical evidence is not conclusive because of the small sample size and because illite can be secondary (e.g. as in the Sheigra and Staca palaeosols of Retallack \& Mindszenty1994). Basic geochemical evidence from boron concentrations could and should be superseded by future studies using more modern methods to definitively determine non-marine vs marine affinity of the Diabaig shales, such as isotopes of transition metals, or concentrations of rare earth elements.

The Meall Dearg Formation is less studied than the Bay of Stoer Formation, it comprises planar cross-bedded sandstones, andincludes some fluvial conglomerates at Stac Fada. The interpretation of the Meall Dearg Formation as a series of alluvial transverse bar deposits that formed a single distributary system is based on similarities of these planar cross-bedded sandstones to those of Recent deposits of the Platte River, Nebraska (Stewart 2002). A combination of cross-beds and provenance data ( $\mathrm{K} / \mathrm{Rb}$ and $\mathrm{La} / \mathrm{Th}$ ratios) suggest that the source area for the Meall Dearg Formation was located to the east of the basin (Stewart 2002). The terrestrial setting for these likely fluvial, uppermost Stoer Group rocks is unchallenged.

The successive Stoer Group units are well exposed at Enard Bay (Figs 1 \& 6), where clasts derived from the Lewisian gneiss are encased in cements of silica (first phase) and calcite (second phaselinked to the Poll a Mhuilt Member) overlie the Lewisian-Torridonian contact (Figs 3 \& 6). Wrinkled, arguably stromatolitic, limestones of the Poll a Mhuilt Member (Bay of Stoer Formation; Stewart 2002) are developed on the weathered Lewisian surface. That the weathered unconformity was an exposed land surface is taken from lateral correlations, and is not inferable directly from the Enard Bay stratigraphy alone. In part this is because only a few thin tabular beds of red sandstone, and of mottled green and red siltstones and mudstones, separate the Poll a Mhuilt limestones from the 
unconformably overlying erosively-based conglomerates and conglomeratic red sandstones of the basal Diabaig Formation (Stewart 2002; Figs 2 \& 6).

\section{The Sleat Group}

To date, the relationship between the Stoer Group and the Sleat Group, part of the Kishorn Nappe, which crops out predominantly on the Isle of Skye, has not been determined (Figs $1 \& 2$ ). It is possible that the Stoer and Sleat Groups were contemporaneous, but Stewart (2002) discounts this because the Sleat Group contains porphyry pebbles, and the Stoer Group does not. Peach et al. (1907) mapped the boundary between the Sleat Group and the Torridon Group as conformable, while Sutton \& Watson (1964) believed they saw inter-fingering of Sleat Group sedimentary rocks with those of the Applecross Formation of the Torridon Group. Stewart (2002) agreed with the assertion that the Torridon Group conformably overlies the Sleat Group, but also stated that: "at present the Sleat Group cannot plausibly be correlated with anything". The supposition that the Sleat Group is correlative with the Torridon Group is inconsistent with detrital U-Pb zircon ages in the Loch na Dal to Kinloch formations, which are distinctly older $(1247+/ 34 \mathrm{Ma})$ than those of the Torridon Group (Kinnaird et al. 2007). There still seems no consensus on correlation of the Sleat Group with other Torridonian units (e.g. Spinks et al. 2014).

The Rubha Guail Formation lies unconformably on Lewisian basement gneiss (Fig. 2), and clasts of the latter are found in a breccia above this unconformity. The remainder of the formation is coarsegrained sandstone with trough cross bedding, wave ripples and desiccation cracks and overall upward fining. These sandstones are capped by the Loch na Dal Formation (Fig. 2), which includes laminated dark grey siltstones with phosphatic horizons. Stewart (2002) interprets the succession as representing transgression of a lake over alluvial fan sands. There are some coarser trough crossbedded sediments at the top of the Loch na Dal Formation, and these can be interpreted as sediment filling of the lake via progradation of a clastic fan (Stewart 2002). Rocks of the Beinn na Seamraig and Kinloch formations (Fig. 2) are dominantly cross-bedded sandstones that were strongly affected by soft-sediment deformation: a characteristic also seen in the overlying Applecross Formation of the Torridon Group. Shales in the Kinloch Formation have been considered to have been deposited during either "transgressive lacustrine or shallow marine episodes" (Stewart 2002), and Kinnaird et al. (2007) highlighted that these fine grained units as a $\mathrm{n}$ important difference between the rocks of the upper Sleat Group and the coarser-grained monotonous sandstones at the base of the Torridon Group in the Kishorn Nappe. Given the strong sedimentological evidence that 
the coarse-grained facies were deposited in fluvial and alluvial environments, and the lack of marine indicators like tidal drapes or seawater evaporites, it is arguably most parsimonious to ascribe the Sleat Group shales to a lacustrine environment.

\section{The Torridon Group}

An unconformity spanning some 130 to 230 million years (Parnell et al. 2011; Turnbull et al. 1996) divides the Stoer Group from the much younger Torridon Group (Fig. 2). The Diabaig Formation at the base of the Torridon Group (though absent in the Kishorn Nappe area) comprises three units: a conglomerate with clasts of gneiss, a conglomerate with clasts of sandstone, and grey shale. The conglomerate units can be seen at Enard Bay (Figs 1, 6 \& 7a) to unconformably overlie the Bay of Stoer Formation, and have here been interpreted as having formed in valley-confined alluvial fans (Stewart 2002; Rodd \& Stewart 1992). The grey shale unit at Badenscallie (Fig. 7b) has randomly aligned symmetrical bifurcating ripples suggesting deposition under influence of oscillating waves (see Tucker 2011),. Note that symmetrical-ripple forming waves are common in lakes, and this does not imply a marine setting. Desiccation cracks filled with sediment from the bed above occur in abundance on some bedding plains, but are absent from others. They are markedly wide, some 2$3 \mathrm{~cm}$ across.

Sandy shoreline facies of the Diabaig Formation, interpreted as associated with high rates of deposition, crop out at Shieldaig on Loch Torridon, whereas muddier shoreline facies are preserved across the loch at Diabaig. Sandy prodelta facies include event bed sandstones near the Fish Farm at Shieldaig and at Brochel and Fladday on Raasay. The interpreted deepest water Diabaig Formation facies, laminated dark shales, are seen at Badachro, though actual depths are hard to estimate.

The Diabaig Formation is currently considered as a lacustrine deposit owing to its infilling of ancient valley systems and its lack of tidal and directional flow deposits and its small wavelength wave ripples (Stewart 2002; Battison \& Brasier 2012). Further evidence that the Diabaig Formation grey shales were deposited in a non-marine setting comes from the boron content of the illite component (Stewart \& Parker1979). The latter authors noted that boron concentrations in illite of brackishmarine shales are commonly $200-500 p p m$, whereas illite from six horizons of the grey shale at Diabaig had boron content in the range 77-113 ppm (Stewart \& Parker1979). More up-to-date geochemical techniques are yet to be applied to these rocks. 
The nature of the contact between the Diabaig Formation and the Applecross Formation has been widely debated. A conformable relationship between the two formations, but without interfingering, has been inferred (Stewart 2002), while Kinnaird et al. (2007) raised the possibility of a disconformity between the two. Their reasoning was a sharp change from locally-sourced siliciclastic grains in the Diabaig Formation to monotonous sandstones and conglomerates of wider provenance in the Applecross Formation. This is consistent with a 'hiatal surface' associated with a change in palaeoenvironment (e.g. dominantly lacustrine to dominantly fluvial), but Kinnaird et al. (2007) provided no firm evidence for a major temporal discontinuity between the Diabaig and Applecross formations. Support for a stratigraphic break between deposition of the Diabaig Formation and the remainder of the Torridon Group does however come from Raman spectroscopic analysis of organic carbon preserved within the Diabaig Formation (Muirhead et al. 201*). Raman data show that organic carbon from the Diabaig Formation and from the Stoer Group exhibit a higher degree of structural ordering than equivalent material from shales higher in the Torridon Group (Muirhead et al. 201*). This leads Muirhead et al. (201*) to suggest the Diabaig Formation sediments were heated during an orogenic event that preceded deposition of the Applecross Formation.

Sedimentologists who have examined the pink sandstones of the Applecross Formation (recently including Owen \& Santos 2014; lelpi \& Ghanassi 2015) are united in their interpretation of deposition in terrestrial fluvial to alluvial settings. On the Stoer Peninsula, for example, active channel deposits include planar to trough and ripple cross-bedded sandstones, planar cross-bedded gravels, and gravel sheets. Channel abandonment deposits include parallel bedded and ripple crosslaminated siltstones, with rare trough cross-beds (lelpi \& Ghanassi 2015), and the associated conglomerates and sandstones around Cape Wrath were interpreted as alluvial fan deposits (Williams 2001). This package fines upward overall, although more typical of alluvial fan sedimentation are the component coarsening upward cycles that make up the fan. Each of these is around 6-8m thick, consisting of cross-bedded sandstones overlain by conglomerates and sandstones, and finally tabular pebbly conglomerates (Williams 2001).

Soft sediment deformation structures including convolute lamination, overturned cross-beds and diapiric structures are very common in the Applecross Formation (Owen1995; Williams 2001; Owen \& Santos 2014). Owen \& Santos (2014) considered that a high groundwater level contributed to sediment deformation, and that the latter was triggered by flood-induced turbulence, seismicallyinduced liquefaction of waterlogged sediments, and upwelling groundwaters. Absence of vascular plant roots that bind sediment and remove water was surely a contributing factor here. 
Above these terrestrial Applecross Formation rocks are the sandstones and shales of the Aultbea Formation (Fig. 9). Kinnaird et al. (2007) considered the Applecross and Aultbea formations to have been deposited in one continuous phase on the basis of lithological similarities between the two. On this point they are in agreement with Stewart (2002) who considered differences between the Applecross and Aultbea formations to be "mere facies", distinguished solely by an absence of pebbles in the Aultbea Formation. There is a thin grey shale at the base of the Aultbea Formation (Fig. 9a), from which organic-walled microfossils have been reported (Zhang et al. 1981; Zhang 1982). Contrary to suggestions in Wellman \& Strother (2015), Zhang (1982) did not favour a marine setting for the shale of the Aultbea Formation that crops out on Tanera Beag. Rather, he concluded that the low taxonomic diversity of the microbiota was consistent with a restricted setting "such as a marine embayment or a lake". On the basis of stratigraphic and sedimentological evidence the most parsimonious explanation for the shale (Fig. 9a) is that it was deposited in a lacustrine setting.

At the top of the Torridon Group is the Cailleach Head Formation (Fig. 10). This comprises at least 15 (Stewart 2002) coarsening upward cycles, from grey shales to medium grained red sandstones. Stewart (2002) interpreted the shales as derived from moderately deep-water muds deposited in a freshwater lake, into which fluvial deltas prograded. This interpretation has largely been followed in subsequent publications by other authors (e.g. Battison \& Brasier 2012). Park et al. (2002) highlighted desiccation cracks near the tops of the grey shale units as evidence for exposure. The delta toe siltstones overlying the shales are fine grained sandstones that exhibit linguoid ripples, whereas the delta top sediments are slightly coarser grained and exhibit flat bedding, current lineation, wave ripples, planar cross-beds and drag marks (Stewart 2002). Fluvial sandstones at the top of each cycle are medium grained and trough cross-bedded. Evidence for a lacustrine origin of the Cailleach Head Formation has been said to come from the small wavelengths of the wave ripples (Battison \& Brasier 2012), a feature observed throughout the Torridonian strata. Battison \& Brasier (2012) concluded this was the result of a short wave fetch in a "small and restricted water body" and was inconsistent with ripple formation on the margins of an ocean, although this is questionable.

In summary, sedimentologists and stratigraphers seem united in their interpretations that the coarser grained Torridonian sediments (e.g. Fig. 9b) are terrestrial in origin. It is curious that past doubts (prior to Stewart 2002) surrounding the terrestrial versus marine affinity of Torridonian rocks have mostly centred on the finer grained sedimentary facies (Zhang1981; Park et al. 2002). Sedimentologists, it seems, are inherently comfortable with conglomerates and coarse sands being fluvial to alluvial, while doubts are allowed to linger that immediately adjacent shales might reflect 
marine transgressions. On the contrary, evidence that the coarse-grained units were terrestrial is now very firm (e.g. Williams 2001; Stewart 2002; Owen and Santos 2014; lelpi \& Ghanassi 2015) and it is inherently likely that Torridonian lacustrine deposits would be adjacent finer grained units. Any challenge to the current paradigm that the fossil-yielding shales (e.g. Fig. 9a) were deposited in lakes (Stewart 2002) will need to be based on a very robust evidence-based case to succeed.

Terrestrial microbial mats in the Proterozoic

Sedimentary evidence for communities of Precambrian microorganisms comes in the form of stromatolites, thrombolites and, in clastic settings, 'microbially-influenced sedimentary structures' (MISS; Noffke et al. 1996; Noffke 2009). Most reports of fossil evidence for Precambrian microbial mats come from marine (or presumed marine; Brasier 2011; Menon et al. 201*) sediments. The record of microorganism habitation of lakes, however, extends at least to the late Archean (Bolhar \& van Kranendonk 2007), 1.5 billion years deeper in time than the 1177+/- 5 Ma Stoer Group. It should therefore come as no surprise that there are reports the Torridonian lakes and adjacent land surfaces were colonized by mats of microorganisms (Prave 2002; Callow et al. 2011).

Stromatolites were reported by Upfold (1984) from the Stoer Group at Stoer (Fig. 11). However others have re-interpreted these as thin layers of calcite interlayered with thin layers of mud containing evaporitic fabrics (Stewart 2002; A.E. Prave, personal communication in Brasier 2011). Examination of the associations between calcite laminae, clastic laminae, evaporitic tepees and desiccation cracks support this abiotic scenario as a more plausible interpretation (Fig. 11). More convincing 'stromatolitic' rocks are found draping an ancient terrestrial surface sculpted from the Lewisian gneiss at Enard Bay (Stewart 2002; Fig. 12a). Thin-sections of these stromatolites reveal them to be comprised of clasts rather than layers of calcite, in a siliciclastic silt-grade matrix (Fig. 12b). A biogenic origin is very plausible, but searches have yet to reveal any conclusive evidence such as entombed microbial fossils.

Another line of evidence for a microbial cover comes from 'microbially induced sedimentary structures' like those reported from the Stoer Group and Diabaig Formation by Prave (2002). Evidence here comes from sedimentary structures including sand-filled desiccation polygons at Rubha Reidh (either uppermost Stoer Group or lower Diabaig Formation) that are each a few centimetres deep that transect ripples. Prave (2002) took this as a sign that mobile, wind-swept sediment capable of forming ripples was locally bound by microbial mats that are analogous to those found in modern deserts (Campbell 1979), with mud veneers on the edges of these polygons caused 
by adherence of fine grained sediment to sticky microbial extracellular polymeric substances (EPS). Prave (2002) also found irregular to rod-shaped sand-rich patches in ripple troughs that might owe their origin to adherence of sand grains on cohesive microbe-inhabited surfaces. Wrinkle structures with sharp to smooth crests, attributed to microbial mats on ephemerally wetted surfaces, were reported from both the Stoer Group and Diabaig Formation rocks (Prave 2002). He noted these wrinkles were better preserved in the fine-grained sandstone facies than coarse-grained units. Callow et al. (2011) focussed on the Diabaig Formation but noted that these wrinkled polygons are widespread in the shallow water facies of the Torridon Group. Where formed of interconnecting positive ridges around 1-3cm diameter polygons they can be termed 'reticulate fabrics' (Fig. 13a), and their shallow, convex counterparts found usually but not exclusively on the soles of beds are known as 'elephant skin' fabrics (Fig. 13b; Runnegar \& Fedonkin 1992; Callow 2011). Elongated, subparallel and slightly sinuous positive ridges termed 'elongated reticulate fabrics' are also found on the top surfaces of Diabaig Formation bedding planes (Fig. 13c; Fig. 13d; Callow 2011). Strother and Wellman (2016) put forward a hypothesis to explain some of these reticulated structures that invokes interaction of raindrops with EPS binding of the sediment, rather than simply wrinkling of microbial mats.

Tentative candidates as recorders of microbial life in the Diabaig lakes are a number of different discoidal fabrics (Fig. 13e; Callow 2011). These range from $<1 \mathrm{~cm}$ diameter sub-circular to circular

361 'pimples' that might be gas dome features caused by biofilm decay, to $<1 \mathrm{~cm}$ discoidal structures that have shallow positive relief and that might have formed around circular microbial colonies, and uniformly 5mm diameter high-relief discoids found at Brochel (Fig. 13e) that Callow et al. (2011) tentatively ascribed to photosynthetic bacterial or even algal colonies.

Earth's oldest terrestrial eukaryotes

Organic remains and microscopic carbonaceous compressions have been extensively reported from the grey shales of the Stoer, Aultbea, and Applecross formations (Cloud \& Germs 1971; Downie 1962, 1984; Naumova \& Pavlovsky 1961; Zhang 1982). The Torridon organic structures have been imaged and analysed by a variety of petrographic techniques (including by Strother et al. 2011; Battison \& Brasier 2012; Wacey et al. 2014; Wellman \& Strother 2015; Strother \& Wellman 2016; Figs 14-16). They are found to form populations of consistent sizes and morphologies, indicating that they are not abiotic contaminants introduced by a particular preparation method, or artefacts of a particular type of analysis. 
The shale-hosted organic microfossils (e.g. Zhang 1981, 1982) are flattened and lack secondary mineralisation. Formal taxonomic treatment was first attempted on these, shale-hosted, fossils by Zhang (1982).

From the Aultbea Shales, Zhang (1981) described spheroidal to ellipsoidal sphaeromorph cryptarchs, mostly 5 to $35 \mu \mathrm{m}$ in diameter, but up to $80 \mu \mathrm{m}$ across, and lacking excystment structures and ornamentation. Zhang (1982) named a varied group of sphaeromorph specimens as belonging to a single new genus, Torridonophycus lepidus. Zhang (1981) also found 5 to $10 \mu \mathrm{m}$ wide aseptate filaments described as nematomorph cryptarchs, named by Zhang (1982) as discarded sheaths of filamentous cyanobacteria (including Syphonophycus beltensis Horodyski, and Eomycetopsis crassiusculum Horodyski). The true diversity of the Torridon Group microfossils was recognized by Strother et al. (2011) who identified several groups of organisms: (1) single-celled sphaeromorphs and other likely eukaryotic forms; (2) multi-walled and colonial forms; (3) organisms with complex morphologies; (4) prokaryotes; and (5) specimens with other characters. They (and more recently Wellman \& Strother 2015) noted the biota is dominated by the sphaeromorphs, especially of the genus Leiosphaeridia. Unlike Zhang (1981), Strother et al. (2011) were able to identify simple median splits and circular pylomes as excystment features, consistent with eukaryotic cell organisation. Strother et al. (2011) identified thicker walled and granae-ornamented Lophosphaeridium sp. cysts that were encased within thinner-walled vesicles. They interpreted the external vesicles as the original vegetative cell walls. This, again, was evidence of eukaryotic cell organisation from fossil organisms that inhabited the Torridonian lakes.

Battison (2012) and Battison \& Brasier (2012) studied phosphatic material from the Torridon Group and identified four principal architectural types of microfossil in their thin-sections (Figs 14-16). These were: 1 ) isolated coccoids, up to 450 microns in diameter (though with a mean diameter of $16.1 \mu \mathrm{m})$, broadly comparable with Leiosphaeridia spp; 2) clusters of coccoids up to $130 \mu \mathrm{m}$ long that include spherical to ellipsoidal cells which may or may not be surrounded by a single external membrane, comparable with Eoentophysalis spp. and Myxococcides spp. (e.g. Butterfield et al. 1994); 3) Non-septate filaments, described as empty tubular sheaths mostly preserved as short broken fragments up to $100 \mu \mathrm{m}$ long, broadly resembling Siphonophycus spp.; and 4) very rare septate filaments, with cell walls that denote oblong cells separated by straight partitions, with a bimodal size distribution of either 1.5 or $12.5 \mathrm{~mm}$ diameter, broadly comparable to Eomycetopsis spp. Based on observed differences in cell wall opacity and colour (dark brown, opaque and rigid vs light brown, translucent and more flexible) Battison \& Brasier (2012) further subdivided these four architectural types to give eight morphotypes (i.e. light and dark versions of each architectural type). 
407 A formal taxonomy was attempted by Battison (2012) for specimens from the Torridon Group but not previously published. We present this in Figs 14-16 and the Supplementary Information, with reference to standard naming and descriptive protocols. Samples are compared with previously described Proterozoic taxa, including synonymies where relevant, and a total of 25 species of 17 genera were identified. Eight forms were described but unnamed. Specimens are now deposited in the Martin Brasier archive at Oxford Museum of Natural History unless otherwise stated. Locations of fossil individuals within slides are identified by a mark on section backing glass, made with a diamond pen.

The microfossils reported by Battison \& Brasier (2012) were phosphate-hosted, consisting of carbonaceous structures suspended within a matrix of amorphous sedimentary phosphate. They are fossilized in a manner that loosely resembles that seen in many Proterozoic chert microfossil assemblages, like the Bitter Springs Chert (Schopf 1968) and the Gunflint Chert (Barghoorn \& Tyler 1965). The original organic matter of the Torridon cells remains well preserved within apatite matrices (Wacey et al. 2014), and differs from examples of fossils pseudomorphed by apatite like some Cambrian soft tissue preservation (Brasier 1990) or Ediacaran-aged Doushantuo-type assemblages (Xiao et al. 1998). We now consider how many of these lacustrine microfossils came to be encased in phosphatic tombs, where they remained for a billion years.

\section{Phosphogenesis and preservation in the Torridonian lakes}

The Diabaig phosphatic lagerstätte are currently the earliest known terrestrial phosphate deposits. They can be traced across some $100 \mathrm{~km}$ of outcrop and range across the full spectrum of palaeoenvironments, except for facies here interpreted as the most sand-rich palaeo-shorelines (Fig. 8). These phosphatic lagerstätte are also known from the Sleat Group of Skye, and the Cailleach Head Formation (Fig. 10b). Together they provide some of the finest quality preservation seen in any Proterozoic ecosystem (Strother et al. 2011; Battison \& Brasier 2012). Cell membranes and even cell contents are well conserved, and seem to be of better quality that those seen in other iconic Precambrian microfossil lagerstätte such as the Gunflint chert (e.g. Wacey et al. 2012 2013; Brasier et al. 2015). As yet, we have no older examples of this taphonomic style than the Diabaig (if we take the Sleat Group to be coeval), at c. 1000 Ma. None has yet been confirmed in the Stoer Group. 
In the Torridon Group are laterally extensive phosphate bands up to $2 \mathrm{~cm}$ thick; millimetre-thick layers over clastic bedding surfaces; and rip-up clasts $<1 \mathrm{~cm}$ thick and up to $3 \mathrm{~m}$ long (Battison \& Brasier 2012). Phosphates examined by Battison \& Brasier (2012) have grain sizes from $500 \mathrm{~nm}$ to $10 \mu \mathrm{m}$, some parts being Fe-rich and others not so, though all types and grain sizes include fossilized carbonaceous microorganisms.

The Diabaig phosphates formed under conditions in which there were no metazoan guts or bioturbation (Brasier et al. 2011). They are also distinctive owing to their rapid formation in the shallow photic zone of lakes. They differ in this respect from phosphate in the 1900 Ma Gunflint Formation (Battison \& Brasier 2012), and from Ediacaran to Phanerozoic examples, which tend to be from marine shelf to upper slope settings (e.g. Shields et al. 2000; Brasier \& Callow 2007; Brasier et al. 2011).

Multiple hypotheses need to be considered to explain phosphogenesis in the Diabaig lake sediments. Battison (2012) considered possible sources of phosphate ions, concluding that dissolved ions would have entered the lake in river waters, before being taken up by microbes for use in structural components and metabolic processes. Phosphate ions would also have been sequestered within EPS mucilage of benthic microbial mats, and adsorbed to the surfaces of iron oxides and hydroxides in oxic conditions. Under reducing conditions desorption of phosphate ions from surfaces of iron oxides and hydroxides may occur (i.e. the 'iron pump and shuttle' of Shaffer 1986).

Seasonal formation of ferruginous anoxic conditions in the deeper lake environments could plausibly have allowed phosphate accumulation in the lake water column during summer thermal stratification and meromixis of a stratified lake. This phosphate could then have been flushed to the surface waters during autumnal mixing of the water mass. Alternatively Battison \& Brasier (2012) tentatively considered the possibility that breakdown of seasonal blooms of planktonic and benthic microbial communities, aided by heterotrophic bacteria, could have produced phosphatesupersaturated waters in the seston layer. Death and decay of the biota will also have locally made zones of chemical reduction around the sediment: water interface, leading to release of phosphate ions from iron oxide surfaces. This latter model (Battison 2012) draws a distinction between pure 467 phosphatic textures formed above the sediment: water interface and grainy phosphate textures 468 formed below microbial mats and within the sediment, implying a soupy seston layer on the lake floor. Strother \& Wellman (2016) described a new species from the Torridon Group (and also the 
470 Nonesuch Formation of Michigan, USA), Eohalothece lacustrina, of strikingly similar morphology to

471 the modern colonial cyanobacterium Microcystis. On the basis of morphological similarities they

472 suggested that Eohalothece might have been a prolific producer of phosphatase inhibitors (like

473 modern Microcystis). Such inhibitors prevent release of inorganic phosphate from organic

474 compounds, so potentially contributing to phosphate build-up around organics at the bottom of the

475 Torridon lakes. However, as noted by Strother \& Wellman (2016), such an explanation is incomplete

476 because phosphates are lacking from the Nonesuch Formation in which Eohalothece is also found.

477

478

Several field observations are consistent with the Diabaig Formation phosphates having initially formed as a gel. These include the rarity of intra-formational clasts within the relatively pure phosphate; evidence for soft-sediment deformation of the phosphate; and upward gradation from granular phosphate to pure phosphate. There is some evidence that the inferred phosphatic gels were in part suspension load within the lake waters. This includes the dominance of coccoids and acritarchs within these phosphates, and a rarity of (benthic?) filamentous fabrics; a rarity of MISS and mat fabrics within the phosphate layers; and mud-drape-like behaviour over rippled bedding surfaces. Field observations also point towards rapid and syn-sedimentary generation of phosphatic gels, rather than slow, diagenetic phosphate growth. Here evidence includes intercalation of phosphates with rippled sandstones, as at Badenscallie and Rubha; intercalation of phosphates with thick sheet sands, as at Dornie; the thin nature of many laminae that are best interpreted as 'event layers'; and the presence of phosphatic rip-up clasts as at Cailleach Head.

That the Torridonian phosphates are associated with green sands and muds, rather than red layers, might imply phosphate formation in reducing conditions. The good preservation of carbonaceous matter within the phosphates might also be taken as evidence for phosphate formation under reducing conditions. Association of iron phosphate and iron silicate minerals like chlorite and glauconite with the microfossil-preserving phosphates might also imply reducing conditions. However, evidence for redox oscillations, at least in the sediment pore waters, comes from the common alternations between green or phosphatic layers with red sandstone layers. Sedimentary structures including rippled sandstones with desiccation cracks and rain pits surely imply at least proximity of the zone of phosphate generation to an oxygenated environment. 
501 It is striking that the Diabaig Formation outcrops at Badenscallie and Rubha (Fig. 1) are more

502 phosphate rich than Torridonian rocks elsewhere, and we can only speculate on reasons for this. It is 503 possible, for example, that prevailing winds pushed planktonic blooms to these lagoonal

504 embayments, where the dead organisms sank as flocculent organic carbon. This could have caused 505 or strengthened local redox gradients within the water column, allowing an 'iron pump' to produce 506 'pelagic' phosphates and silicates in greater abundance at Badenscallie and Rubha than in other 507 places around the lake.

Reasons that the preservation of carbonaceous microfossils is so good in the Torridon Group include the lack of scavenging organisms in the Neoproterozoic; lack of bioturbation of the seston layer, allowing phosphate gel settling and crystallisation; low oxygen levels; lack of bicarbonate and sulphate ions, favouring precipitation of calcium phosphate; and lack of sulphate-reducing bacteria that might otherwise have consumed the organic carbon. Use of modern micro-analytical techniques (FIB-milling to produce TEM wafers and ChemiSTEM elemental maps), however, revealed the highest fidelity preservation to be associated with Fe-rich clay mineralisation directly around the cellular material (Wacey et al. 2014). Precipitation of this Fe-rich clay mineral was interpreted to have been microbially-mediated, with K-rich clays forming once the iron supply had been locally exhausted (Wacey et al. 2014). Lack of sulphate in the lake waters was seen as critical to this style of preservation that fossilizes original cellular material (not mere pseudomorphs). This was because the iron that forms the clays might otherwise have been extracted from sub-oxic lake waters as pyrite.

Contrasting models for early lake ecosystems

The Stoer lake ecosystems (upper Clachtoll and Poll a'Mhuilt ) and the Diabaig lake ecosystems provide us with fascinating opportunity to understand early life on land. Being small aqueous ecosystems, lakes are be remarkably sensitive indicators of environmental conditions, making ancient lakes a good place to test biogeochemical models for the early atmosphere (e.g. Parnell et al. 2010; Cumming et al. 2013). 
531 The Diabaig and Stoer lakes are especially fascinating because both were formed above the same

532 Lewisian gneiss basement topography and so both had access to much the same basement

533 geochemistry. It is interesting to note here that modern lake ecosystems sitting on Lewisian rock

534 (peat with little soil or clay) have an ecology that is distinct from elsewhere in the UK, provided

535 highly diverse desmid green algae, above both base-rich and base poor Lewisian rock (Pentecost 536 1984).

537

538 Although separated by some $200 \mathrm{Ma}$, both kinds of lake ecosystem were also formed near the end 539 of 'the Boring Billion' during the time when eukaryotic green algae (and presumably other protistan 540 groups) were starting to expand and the eukaryote chloroplast was emerging (Brasier \& Lindsay 541 1998).

543 Prior to the origins of bioturbation near the start of the Cambrian (Mcllroy \& Logan 1999), mineral 544 precipitation (phosphate, carbonate, silicate) seemingly took place more freely across a redox 545 boundary close to, or even at, the sediment-water interface (Brasier et al. 2011). The Torridonian 546 ecosystems also evolved well before the changes in the sediment supply brought about by vascular 547 plant evolution, with its influence on sediment erosion and stabilisation (Davies \& Gibling 2010; 548 Gibling \& Davies 2012) and on carbonate calcrete soil formation (Brasier 2011).

So why are the Diabaig and Stoer lake sediments, ecosystems and taphonomic facies so distinct from each other? We can certainly argue that the palaeoclimatic and palaeogeographic contexts were different, and that this had a marked influence on the biogeochemistry of each lake. These factors in turn greatly influenced the ecology and microbial processes, including the taphonomic degradation of organic matter on the lake floor.

The Stoer lakes seemingly formed under conditions of interior, closed drainage during a warm semiarid climate conducive to evaporation and the formation of calcium carbonate and calcium sulfate. This matters because of the known affinity of phosphate ions for iron oxide $\left(\mathrm{Fe}^{3+}\right.$, to form ferriphosphate) and for carbonate ions (to become incorporated in the lattice), so both may have helped to inhibit the formation of calcium phosphate in the Stoer lake waters. Abundant sulfate ions 
within the Stoer lakes also allowed for a fully expressed range of sulfur isotopes during bacterial sulfate reduction, and perhaps for localised bacterial sulfide oxidation (Parnell et al. 2010). Freely available sulfate ions may also have enabled episodically euxinic conditions in the deeper lake, perhaps facilitated by increasing levels of sulfate formation at a time of rising oxygen level. Spinks et al. (2010) studied reduction spots from the Bay of Stoer Formation, and argued that the presence of vanadium-rich mica (roscoelite) in the centres of some of the spots was consistent with microbial reduction of the sediment.

In contrast, the younger Diabaig lake formed under conditions with open rather than enclosed drainage, and the climate was conceivably more temperate (cooler and more humid), although the extremely high diversity of the microfossil assemblages (maybe over 100 species; Paul Strother pers. comm. 2013) might challenge that view. Neither carbonate nor sulfate grew as authigenic precipitates on the lake floor here. Instead, phosphate ions were concentrated during localised stratification in the water column and sediment, both from the degradation of organic matter, and from an 'iron oxide pump'. Calcium phosphate precipitated freely when redox conditions were suitable (see experimental studies on the taphonomic processes for phosphatization of microorganisms; e.g. Gostling et al. 2008; Raff et al. 2006, 2008). The result of this fortuitous combination of chemistry and biology was truly remarkable three-dimensional preservation of eukaryotic and prokaryotic life in non-marine worlds, 1 billion years ago.

\section{Conclusions}

The pronounced unconformity between Lewisian basement rocks and the Torridonian sedimentary succession was likely an ancient weathered land surface. The Stoer Group is interpreted as terrestrial on the basis of lithologies (red sandstones and conglomerates) sedimentary structures (including cross-bedded sandstones of likely fluvial origin, pseudomorphs after gypsum, small wavelength wave ripples and desiccation cracks from likely lacustrine units) and geochemistry (boron content of illite clays). Like the Sleat Group, the lack of marine indicators like tidal drapes also supports terrestrial environmental interpretations. The Neoproterozoic Diabaig Formation is similarly considered as lacustrine owing to its infilling of ancient valley systems, its lack of tidal and directional flow deposits, its small wavelength wave ripples, and boron content of illite clays. Sedimentologists who have examined the pink sandstones of the Applecross Formation are united in their interpretation of deposition in terrestrial fluvial to alluvial settings on the basis of lithologies and sedimentary structures. Grey shale at the base of the Aultbea Formation, from which organic-walled microfossils 
have been reported, is best interpreted as lacustrine on the basis of stratigraphic arguments. Evidence for a lacustrine origin of the Cailleach Head Formation at the top of the Torridon Group comes similarly from the stratigraphy (overlying terrestrial units) and small wavelengths of the wave ripples. Sedimentologists and stratigraphers seem united in their interpretations that the coarser grained Torridonian sediments are terrestrial in origin. Any challenge to the current paradigm that the associated fossil-yielding shales were deposited in lakes will need to be based on a very robust evidence-based case to succeed.

Abundant evidence that these ancient terrestrial environments were inhabited comes from stromatolites, microbially induced sedimentary structures, and organic-walled microfossils. Organic remains and microscopic carbonaceous compressions are known from the grey shales of the Stoer, Aultbea and Applecross formations, so spanning the time interval and range of environments represented by the Torridonian Supergroup. The organic carbon microbiota were dominated by sphaeromorphs, especially of the genus Leiosphaeridia. The Diabaig phosphatic lagerstätte are currently the earliest known terrestrial phosphate deposits. Excellent preservation of carbonaceous microfossils in these phosphates may result from the lack of scavenging organisms in the Neoproterozoic; lack of bioturbation; low oxygen levels; lack of bicarbonate and sulphate ions; and lack of sulphate-reducing bacteria in the Diabaig lakes. In summary, current evidence points to at least two (Stoer and Torridon) and potentially four (Stoer, Diabaig, Sleat, and Applecross-Aultbea) successive terrestrial worlds, each with lakes inhabited, adapted and modified by populations of benthic and planktonic microorganisms in the Proterozoic.

\section{Acknowledgements}

This article stems from a manuscript that MDB was planning to write with ATB in 2015, with contributions from TC, LB and RC. For any and all oversights or errors ATB apologizes and takes the blame. We thank the reviewers for their suggestions that improved the text. For the well-written sections MDB takes the credit, as in places it draws heavily from his field notes and an unpublished field guide MDB compiled in 2013. In his acknowledgement there he wrote the following: "This guide owes much to field and lab work with my students Tim Culwick, Richard Callow, Leila Battison, Jonathan Antcliffe and David Wacey; to current collaborations with Paul Strother (Boston), Charlie Wellman (Sheffield), John Parnell and Stephen Bowden (Aberdeen); to free exchange of ideas and information with Tony Prave, Richard Butler and Pete Adamson (St Andrews); to the encouragement to pull all this together from Graham and Ying Shields-Zhou (UCL) and from Marten Krabendam 
625 (BGS, Edinburgh); to enthusiasm for early life on land by my son, Alex Brasier (Amsterdam); and to 626 the initial encouragement from my old colleagues Sandy Stewart and Roland Goldring (Reading) to start looking for Torridonian life back in 1973. (Sorry it took so long!)". We are sure that given the opportunity MDB would have extended his genuine thanks to all scientists that have contributed to understanding of Proterozoic life and environments, and to all those who will carry on efforts to do so, long into the future.

References

AMOR, K., Hesselbo, S.P., PorCelli, D., ThACKReY, S. \& PARnelL, J. 2008. A Precambrian proximal ejecta blanket from Scotland. Geology, 36, 303-306.

BARGHOORN, E.S. \& TYLER, S.A. 1965. Microorganisms from the Gunflint Chert: These structurally preserved Precambrian fossils from Ontario are the most ancient organisms known. Science, 147, 563-575.

BATTISON, L. 2012. Exceptional Preservation of Cells in Phosphate and the Early Evolution of the Biosphere. PhD thesis University of Oxford.

BATTISON, L. \& BRASIER, M.D. 2012. Remarkably preserved prokaryote and eukaryote microfossils within 1Ga-old lake phosphates of the Torridon Group, NW Scotland. Precambrian Research, 196, 204-217.

642 Bolhar, R. \& VAN KRANENDONK, M.J. 2007. A non-marine depositional setting for the northern 643 Fortescue Group, Pilbara Craton, inferred from trace element geochemistry of stromatolitic carbonates. Precambrian Research, 155, 229-250.

BRANNEY, M.J. \& BROWN, R.J. 2011. Impactoclastic Density Current Emplacement of Terrestrial 646 Meteorite-Impact Ejecta and the Formation of Dust Pellets and Accretionary Lapilli: Evidence from 647 Stac Fada, Scotland. The Journal of Geology, 119, 275-292.

648 BRASIER, A.T. 2011. Searching for travertines, calcretes and speleothems in deep time: Processes, 649 appearances, predictions and the impact of plants. Earth-Science Reviews, 104, 213-239.

650 BRASIER, A.T. 2014. Archaean soils, lakes and springs: looking for signs of life. In: DILEK, Y. \& FURNES, H.

651 (eds) Evolution of Archean Crust and Early Life. Modern Approaches in Solid Earth Sciences, 7, 652 Springer-Verlag, Netherlands, 367-384. 
653

654

655

656

657

658

659

660

661

662

663

664

665

666

667

668

669

670

671

672

673

674

675

676

677

678

679

680

BRASIER, M.D. 2013. Green algae (Chlorophyta) and the question of freshwater symbiogenesis in the early Proterozoic. Journal of Phycology, 49, 1036-1039.

BRASIER, M.D., ANTCLIFFE, J.B. \& CALlow, R.H.T. 2011. Evolutionary trends in remarkable fossil preservation across the Ediacaran-Cambrian transition and the impact of metazoan mixing. In:

Aluson, P.A. \& BotTJER, D.J. (eds) Taphonomy: Process and Bias Through Time. Springer, 519-567.

BRASIER, M.D. \& CALLOW, R.H. 2007. Changes in the patterns of phosphatic preservation across the Proterozoic-Cambrian transition. Memoirs of the Association of Australasian Palaeontologists, 34, 377-389.

BRASIER, M.D. 1990. Phosphogenic events and skeletal preservation across the Precambrian-

Cambrian boundary interval. Geological Society, London, Special Publications, 52, 289-303.

BRASIER, M.D., ANTCLIFFE, J.B., SAUNDERS, M. \& WACEY, D. 2015. Changing the picture of Earth's earliest fossils (3.5-1.9 Ga) with new approaches and new discoveries. Proceedings of the National Academy of Sciences, 112, 4859-4864.

BRASIER, M.D. \& LINDSAY, J.F. 1998. A billion years of environmental stability and the emergence of eukaryotes: new data from northern Australia. Geology, 26, 555-558.

ButTerfield, N.J., KNOLL, A.H. \& SWETT, K.1994. Paleobiology of the Neoproterozoic Svanbergfjellet Formation, Spitsbergen. Lethaia, 27, 76-76.

CALLOW, R.H.T., BATTISON, L. \& BRASIER, M.D. 2011. Diverse microbially induced sedimentary structures from 1 Ga lakes of the Diabaig Formation, Torridon Group, northwest Scotland. Sedimentary Geology, 239, 117-128.

CAMPBELL, S. E. 1979. Soil stabilization by a prokaryotic desert crust: implications for Precambrian land biota. Origins of Life, 9, 335-348.

CLOUd, P. \& GeRMS, A. 1971. New Pre-Paleozoic nannofossils from the Stoer Formation (Torridonian), Northwest Scotland. Geological Society of America Bulletin, 82, 3469-3474.

CULWICK, T. 2013. Remarkable preservation of microfossils within 1177Ma and 994Ma Lakes in the Torridonian of NW Scotland. Unpublished MSc thesis, University of Oxford, 1-99.

Cumming, V.M., Poulton, S.W., Rooney, A.D. \& Selby, D. 2013. Anoxia in the terrestrial environment during the late Mesoproterozoic. Geology, 41, 583-586. 
DAVIES, N.S. \& Gibling, M.R. 2010. Cambrian to Devonian evolution of alluvial systems: The sedimentological impact of the earliest land plants. Earth-Science Reviews, 98, 171-200.

DoWNIE, C. 1962. So-called spores from the Torridonian. Proceedings of the Geological Society, 684 London, 160, 127-128.

DoWNIE, C. 1984. Acritarchs in British Stratigraphy. Geological Society of London Special Report 17, 686 Blackwell Scientific, Oxford, 1-26.

687 GIBLING, M.R. \& DAVIES, N.S. 2012. Palaeozoic landscapes shaped by plant evolution. Nature 688 Geoscience, 5, 99-105.

Gostling, N.J., Thomas, C-W., Greenwood, J.M., DOng, X., Bengtson, S., Raff, E.C., RafF, R.A., Degnan, 690 B.M., StAMPANONI, M. \& Donoghue, P.C.J. 2008. Deciphering the fossil record of early bilaterian 691 embryonic development in light of experimental taphonomy. Evolution \& Development, 10, 339-349.

692 IELPI, A. \& GHINASSI, M. 2015. Planview style and paleodrainage of Torridonian channel belts: 693 Applecross Formation, Stoer Peninsula, Scotland. Sedimentary Geology, 325, 1-16.

694 Kinnaird, T., Prave, A., Kirkland, C.L., Horstwood, M., Parrish, R. \& Batchelor, R.A. 2007. The late 695 Mesoproterozoic-early Neoproterozoic tectonostratigraphic evolution of NW Scotland: the 696 Torridonian revisited. Journal of the Geological Society, London, 164, 541-551.

697 MCILROY, D. \& LogAN, G.A. 1999. The impact of bioturbation on infaunal ecology and evolution during 698 the Proterozoic-Cambrian transition. Palaios, 14, 58-72.

699 MUIRHEAD, D.K., PARNelL, J., SPINKS, S. \& BOWDEN, S.A. 201*. Characterization of organic matter in the 700 Torridonian using raman spectroscopy. In: BRASIER, A.T., MCILROY, D. \& MCLOUGHLIN, N. (eds) Earth 701 System Evolution and Early Life: a Celebration of the Work of Martin Brasier. Special Publication of 702 the Geological Society, London, $448,{ }^{* *} *_{-} * *$.

703 NAUMOVA, S.N. \& PAVLovskY, E.V. 1961. The finds of plant remains (spores) in shales of the 704 Torridonian in Scotland. Zapiski Akademii Nauk S.S.S.R, 141, 181-182. (MISS) in Archean and younger, sandy deposits. Earth Science Reviews, 96, 173-180. 
707

708

709

710

711

712

713

714

715

716

717

718

719

720

721

722

723

724

725

726

727

728

729

730

731

732

733

NoffKe, N., GeRDES, G., KLENKE, T. \& KRUMBEIN, W.E. 1996. Microbially induced sedimentary structures examples from modern sediments of siliciclastic tidal flats. Zentralblatt fur Geologie und Palaontologie Teil 1, 307-316.

NoffKe, N., Gerdes, G., KLENKE, T. \& Krumbein, W.E. 2001. Microbially Induced Sedimentary Structures - a new category within the classification of primary sedimentary structures. Journal of Sedimentary Research, 71, 649-656.

OWEN, G. 1995. Soft-sediment deformation in upper Proterozoic Torridonian sandstones (Applecross Formation) at Torridon, northwest Scotland. Journal of Sedimentary Research, 65, 495-504.

OWEN, G. \& SANTOS, M.G. 2014. Soft-sediment deformation in a pre-vegetation river system: the Neoproterozoic Torridonian of NW Scotland. Proceedings of the Geologists' Association, 125, 511523.

Park, R., SteWART, A. \& Wright, D.T. 2002. The Hebridean Terrane. In: TREWIN, N.H. (ed.). The Geology of Scotland. Geological Society, London, 45-80.

PARNELL, J., BOYCE, A. J., ET AL. 2010. Early oxygenation of the terrestrial environment during the Mesoproterozoic. Nature, 468, 290-293.

Parnell, J., Mark, D., Fallick, A.E., Boyce, A. \& Thackrey, S. 2011. The age of the Mesoproterozoic Stoer Group sedimentary and impact deposits, NW Scotland. Journal of the Geological Society, London, 168, 349-358.

Peach, B.N., Horne, J., Gunn, W., Clough, C.T., HinXman, L.W. \& Teall, J.J.H. 1907. The Geological Structure of the North-West Highlands of Scotland. HM Stationery Office.

PenteCost, A. 1984. Introduction to freshwater algae. Richmond Publishing Co, Surrey, UK. 256pp.

PRAVE, A.R. 2002. Life on land in the Proterozoic: evidence from the Torridonian rocks of northwest Scotland. Geology, 40, 811-814.

Raff E. C., Schollaert, K. L., Nelson, D. E., Donoghue, P. C. J. , Thomas, C.-W., Turner, F. R., Stein, B. D., Dong, X., Bengtson, S., Huldtgren, T., Stampanoni, M., Chongyu, Y. \& Raff, R. A. 2008. Embryo fossilization is a biological process mediated by microbial biofilms. Proceedings of the National Academy of Sciences, 105, 360-19365. 
RafF, E.C., VILLINSKI, J.T., TURner, F.R., Donaghue, P. \& RAFF, R.A. 2006. Experimental taphonomy shows the feasibility of fossil embryos. Proceedings of the National Academy of Sciences, 103, 5846-5851.

RETALLACK, G.J. \& MINDSZENTY, A. 1994. Well preserved late Precambrian paleosols from Northwest Scotland. Journal of Sedimentary Research, 64, 264-281.

RODD, J. \& STEWART, A. 1992. Geochemistry, weathering and diagenesis of the Diabaig Formation (Torridon Group) in NW Scotland. Scottish Journal of Geology, 28, 27-35.

Runnegar, B. \& FedonkIN, M. 1992. Proterozoic metazoan body fossils. In: SCHOPF, J.W. \& KLeIN, C. (eds) The Proterozoic Biosphere: a Multidisciplinary Study, Cambridge University Press, 369-388.

RUSSELL, M.J. \& ALLISON, I. 1985. Agalmatolite and the maturity of sandstones of the Appin and Argyll groups and Eriboll Sandstone. Scottish Journal of Geology, 21, 113-122.

SCHOPF, J.W. 1968. Microflora of the Bitter Springs formation, late Precambrian, central Australia. Journal of Paleontology, 42, 651-688.

SHAFFER, G. 1986. Phosphate pumps and shuttles in the Black Sea. Nature, 321, 515-517.

SHIELDS, G., STILLE, P. \& BRASIER, M.D. 2000. Isotopic records across two phosphorite giant episodes compared: the Precambrian-Cambrian and the late Cretaceous-recent. In: GLENN, C., PREVOT-LUCAS, L. \& LUCAS, J. (eds) Marine Authigenesis: From Global to Microbial, SEPM Special Publications, 66, 103116.

SPINKS, S.C., PARNeLL, J. \& BoWDEN, S.A. 2010. Reduction spots in the Mesoproterozoic age: implications for life in the early terrestrial record. International Journal of Astrobiology, 9, 209-216. SPINKS, S. C., PARNELL, J., BOWDEN, S.A. , TAYLOR, RAD \& MACLEAN, M.E. 2014. Enhanced organic carbon burial in large Proterozoic lakes: implications for atmospheric oxygenation. Precambrian Research, $255,202-215$.

STEWART, A.D. 1982. Late Proterozoic rifting in NW Scotland: the genesis of the 'Torridonian'. Journal of the Geological Society, 139, 413-420.

STEWART, A.D. 2002. The Later Proterozoic Torridonian Rocks of Scotland: their Sedimentology, Geochemistry and Origin. Geological Society, London, Memoir 24. 
StEWART, A.D. \& PARKER, A. 1979. Palaeosalinity and environmental interpretation of red beds from the late Precambrian ('Torridonian') of Scotland. Sedimentary Geology, 22, 229-241.

STROTHER, P.K. \& WeLLMAN, C.H. 2016. Palaeoecology of a billion-year-old non-marine cyanobacterium from the Torridon Group and Nonesuch Formation. Palaeontology, 59, 89-108.

Strother, P.K., BATtISON, L., BRASIER, M.D. \& WelLMAN, C.H. 2011. Earth's earliest non-marine eukaryotes. Nature, 473, 505-509.

SUTTON, J. \& WATSON, J. 1964. Some aspects of Torridonian stratigraphy in Skye. Proceedings of the Geologists' Association, 75, 251-IN1.

Teall, J.J.H. 1907. The Petrography of the Torridonian Formation. In: PEACH, B.N., HORNE, J., GunN, W., Clough, C.T., HINXMAN, L.W. \& TeALL, J.J.H. (eds) The Geological Structure of the North-west Highlands of Scotland. Memoirs of the Geological Survey of Great BritainHM Stationery Office, Glasgow, pp. 278-290

TUCKER, M.E. 2011. Sedimentary Rocks in the Field: a Practical Guide. John Wiley \& Sons Chichester, $275 p$.

TURnBulL, M.J.M., Whitehouse, M.J. \& MOORBATH, S. 1996. New isotopic age determinations for the Torridonian, NW Scotland. Journal of the Geological Society, 153, 955-964.

UPFOLD, R.L. 1984. Tufted microbial (cyanobacterial) mats from the Proterozoic Stoer Group, Scotland. Geological Magazine, 121, 351-355.

Wacey, D., Menon, S., Green, L., Gerstmann, D., Kong, C., Mcloughlin, N., Saunders, M. \& Brasier M.D. 2012. Taphonomy of very ancient microfossils from the $\sim 3400$ Ma Strelley Pool Formation and $\sim$ 1900Ma Gunflint Formation: New insights using a focused ion beam. Precambrian Research, 220, 234-250.

Wacey, D., Saunders, M., Roberts, M., Menon, S., Kong, C., Culwick, T., Strother, P. \& Brasier, M.D. 2014. Enhanced cellular preservation by clay minerals in 1 billion-year-old lakes. Scientific reports, 4. doi: 10.1038/srep05841

Wacey, D., Mcloughlin, N., Kilburn, M.R., Sunders, M. , ClifF, J.B. , Kong, C., BARley, M.E. \& Brasier, M.D. 2013. Nanoscale analysis of pyritized microfossils reveals differential heterotrophic 

Figures

consumption in the 1.9-Ga Gunflint chert. Proceedings of the National Academy of Sciences, 110, 8020-8024.

WELLMAN, C.H. \& STROTHER, P.K. 2015. The terrestrial biota prior to the origin of land plants (embryophytes): a review of the evidence. Palaeontology, 58, 601-627.

WILLIAMS, G.E. 1966. Palaeogeography of the Torridonian Applecross Group. Nature, 209, 1303-1306.

WILLIAMS, G.E. 1968. Torridonian weathering, and its bearing on Torridonian palaeoclimate and source. Scottish Journal of Geology, 4, 164-184.

WILLIAMS, G.E. 1969. Characteristics and origin of a Precambrian pediment. The Journal of Geology, $77,183-207$.

WILLIAMS, G.E. 2001. Neoproterozoic (Torridonian) alluvial fan succession, northwest Scotland, and its tectonic setting and provenance. Geological Magazine, 138, 161-184.

WILLIAMS, G.E. 2015. Hydrothermal alteration of Britain's oldest palaeosols: saddle dolomite and smectite at the Lewisian-Torridon Group (early Neoproterozoic) unconformity, NW Scotland. Scottish Journal of Geology, 51, 63-68.

WILLIAMS, G.E. \& SCHMIDT, P.W. 1997. Palaeomagnetic dating of sub-Torridon Group weathering profiles, NW Scotland: verification of Neoproterozoic palaeosols. Journal of the Geological Society, $154,987-997$.

Xiao, S., Zhang, Y. \& KNOLL, A.H. 1998. Three-dimensional preservation of algae and animal embryos in a Neoproterozoic phosphorite. Nature, 391, 553-558.

ZHANG, Z. 1982. Upper Proterozoic microfossils from the Summer Isles, NW Scotland. Palaeontology, $25,443-460$.

ZHANG, Z., DIVER, W. \& GRANT, P.R. 1981. Microfossils from the Aultbea Formation, Torridon Group, on Tanera Beg, Summer Isles. Scottish Journal of Geology, 17, 149-154. 


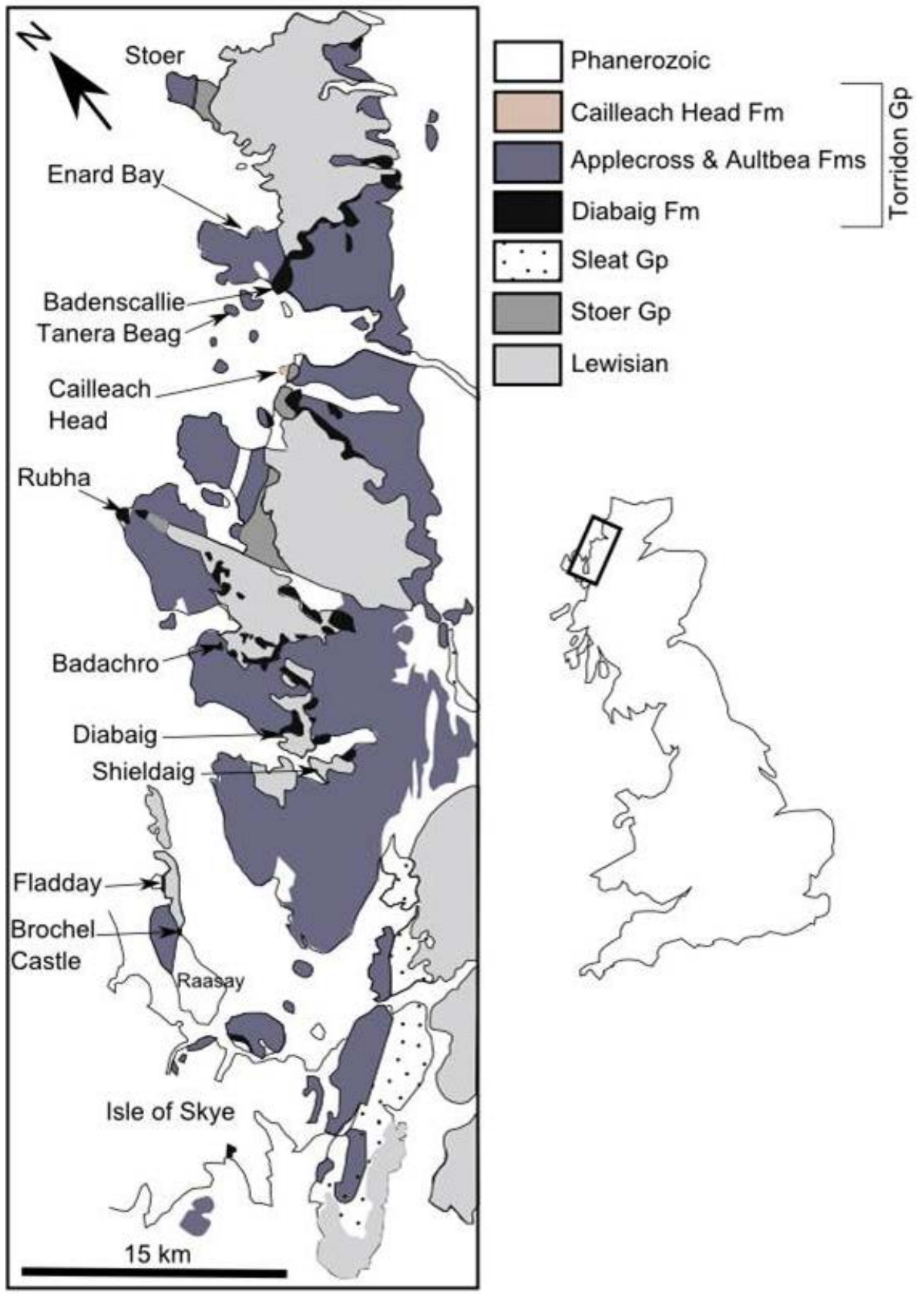

814 Fig. 1: Map showing Torridonian localities in northwest Scotland discussed in the text. Adapted from 815 Battison \& Brasier (2012), who modified the map of Stewart (2002). 


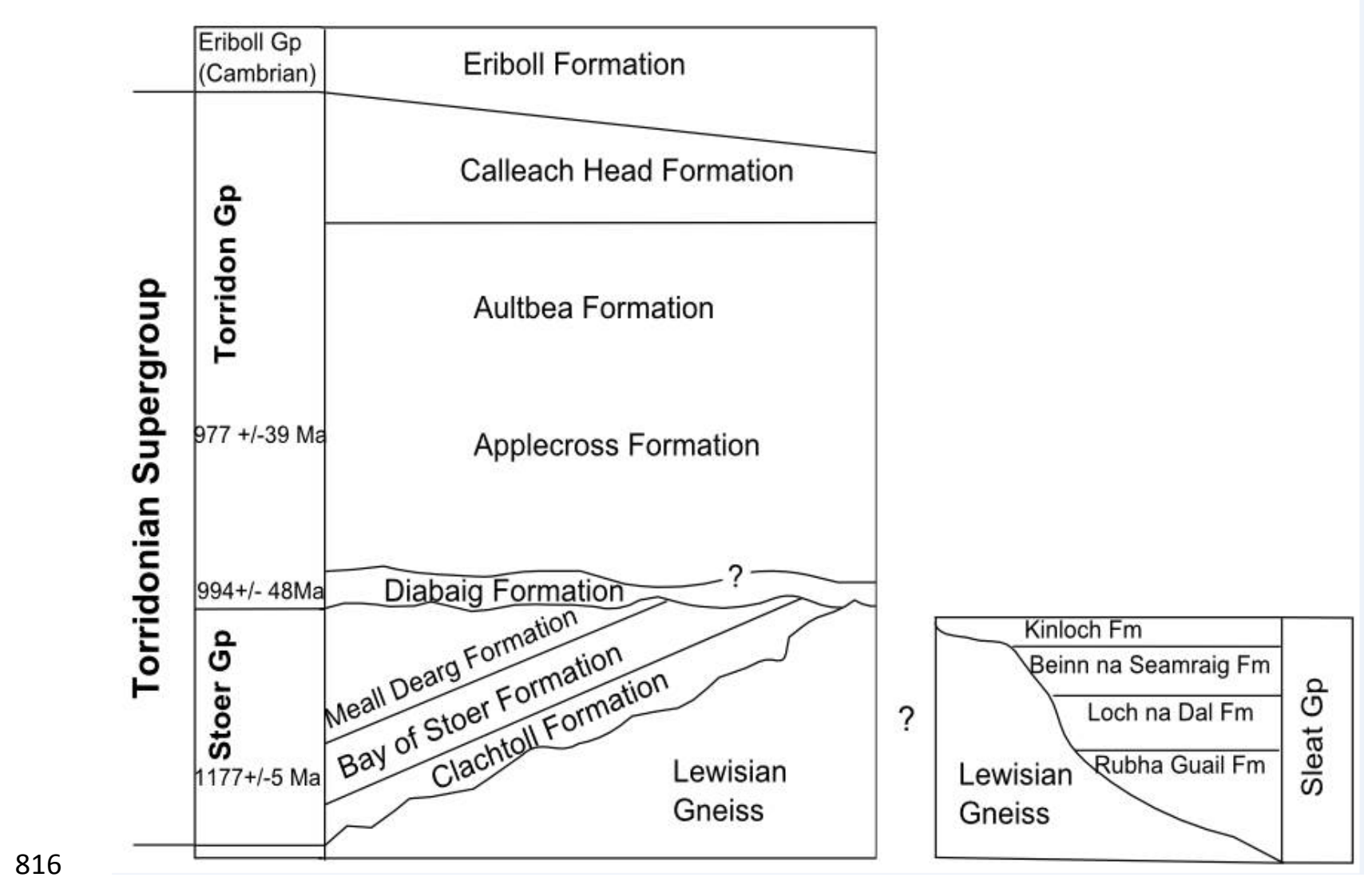

817 Fig. 2: Stratigraphy of the Torridonian, with radio-isotope ages from Parnell et al. (2011) and Turnbull 818 et al. (1996). Adapted from Stewart (2002), Callow et al. (2011) and Battison\& Brasier (2012). 


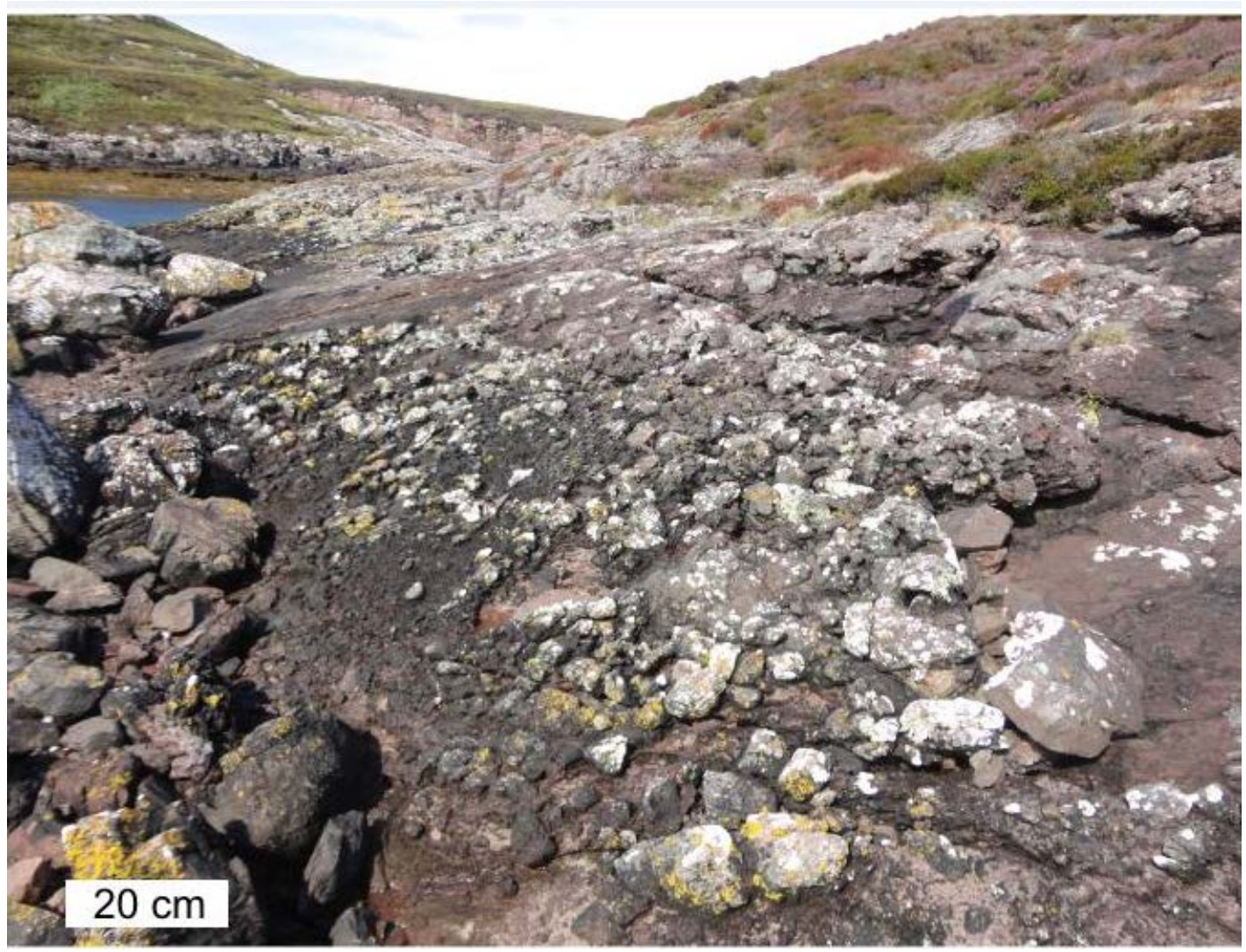

820 Fig. 3: A one billion year old land surface re-exposed: the unconformity between Lewisian

821 metamorphics and Torridonian Supergroup sediments as exposed at Enard Bay. Stromatolitic

822 carbonates of the Stoer Group drape irregularities of this surface (see also Fig. 12). 

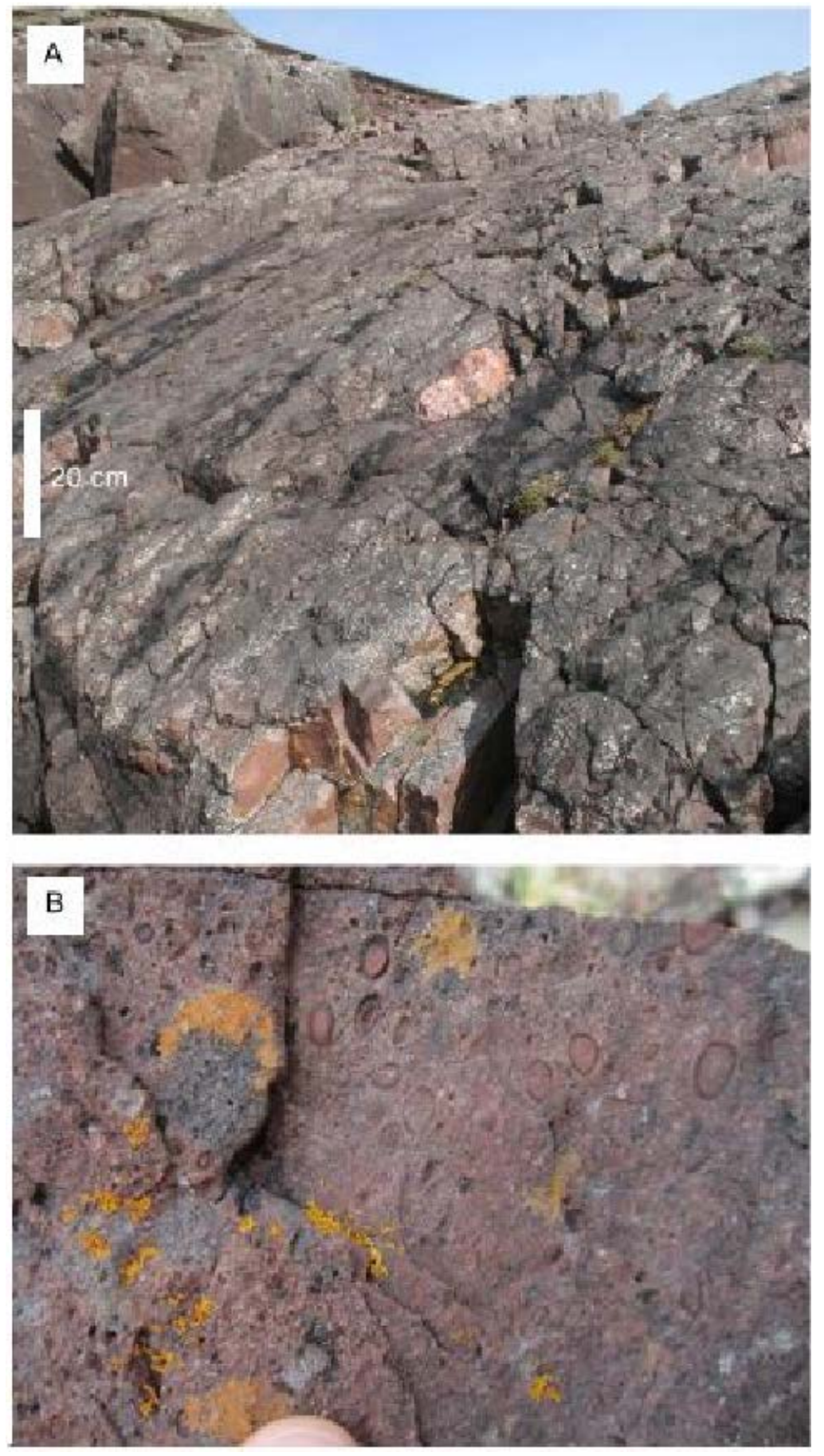

823

824 Fig. 4: Field photographs of the Stac Fada Member: a) at Bay of Stoer; and b) at Enard Bay, the latter 825 showing lapilli. Finger-tip in B for scale. 

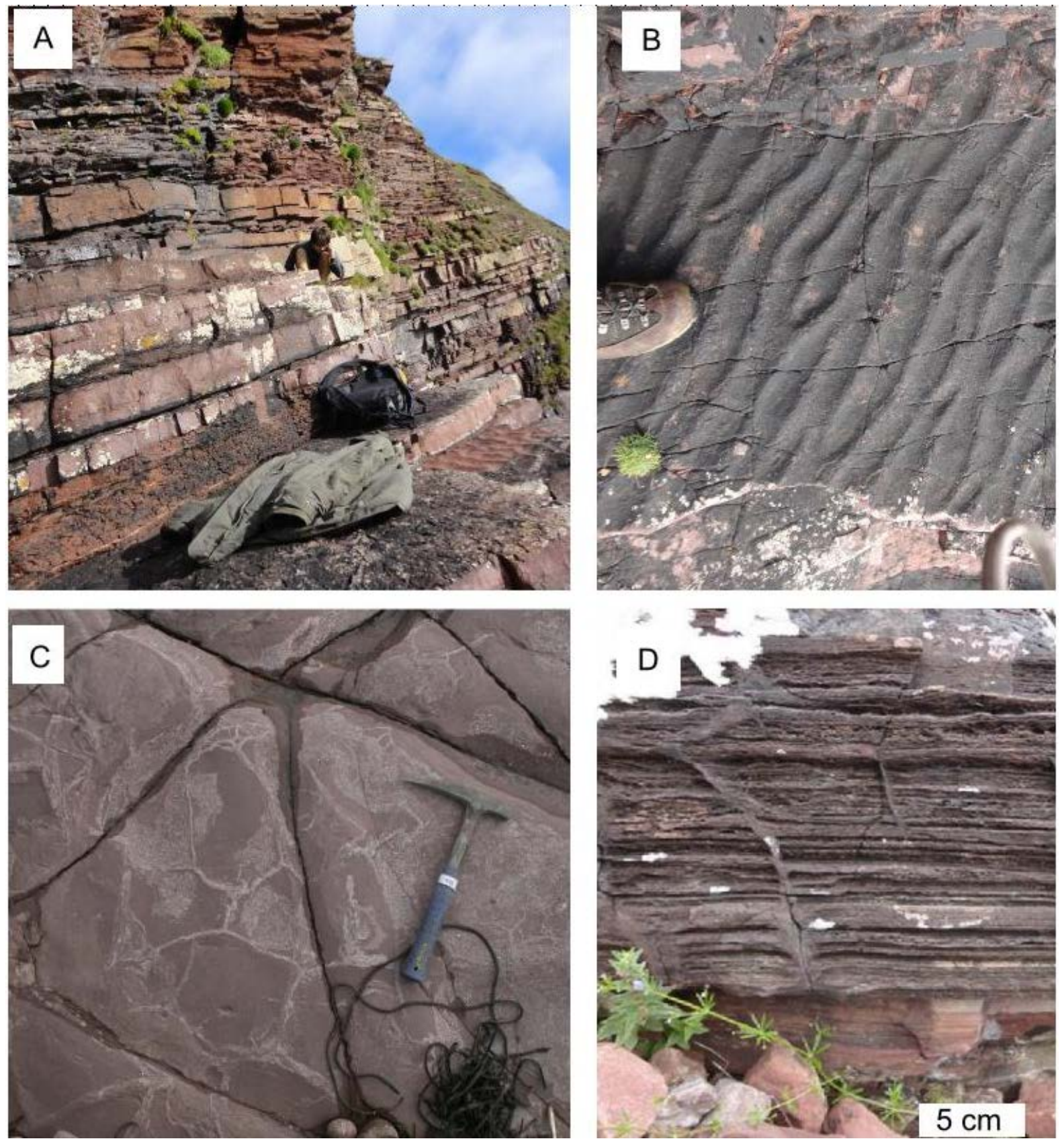

827 Fig. 5: Bay of Stoer Formation field photographs. a) Red coloured sandstones, siltstones and

828 mudstones at Bay of Stoer, including bedding planes that exhibit small wavelength bifurcating wave

829 ripples (b). c) Desiccation cracks in red mudstones on a bedding plane at Bay of Stoer d) Planar

830 laminated mud, followed by alternations of silty carbonate rock and siltstone in the Poll a' Mhuilt

831 Member lake bed, Enard Bay. 


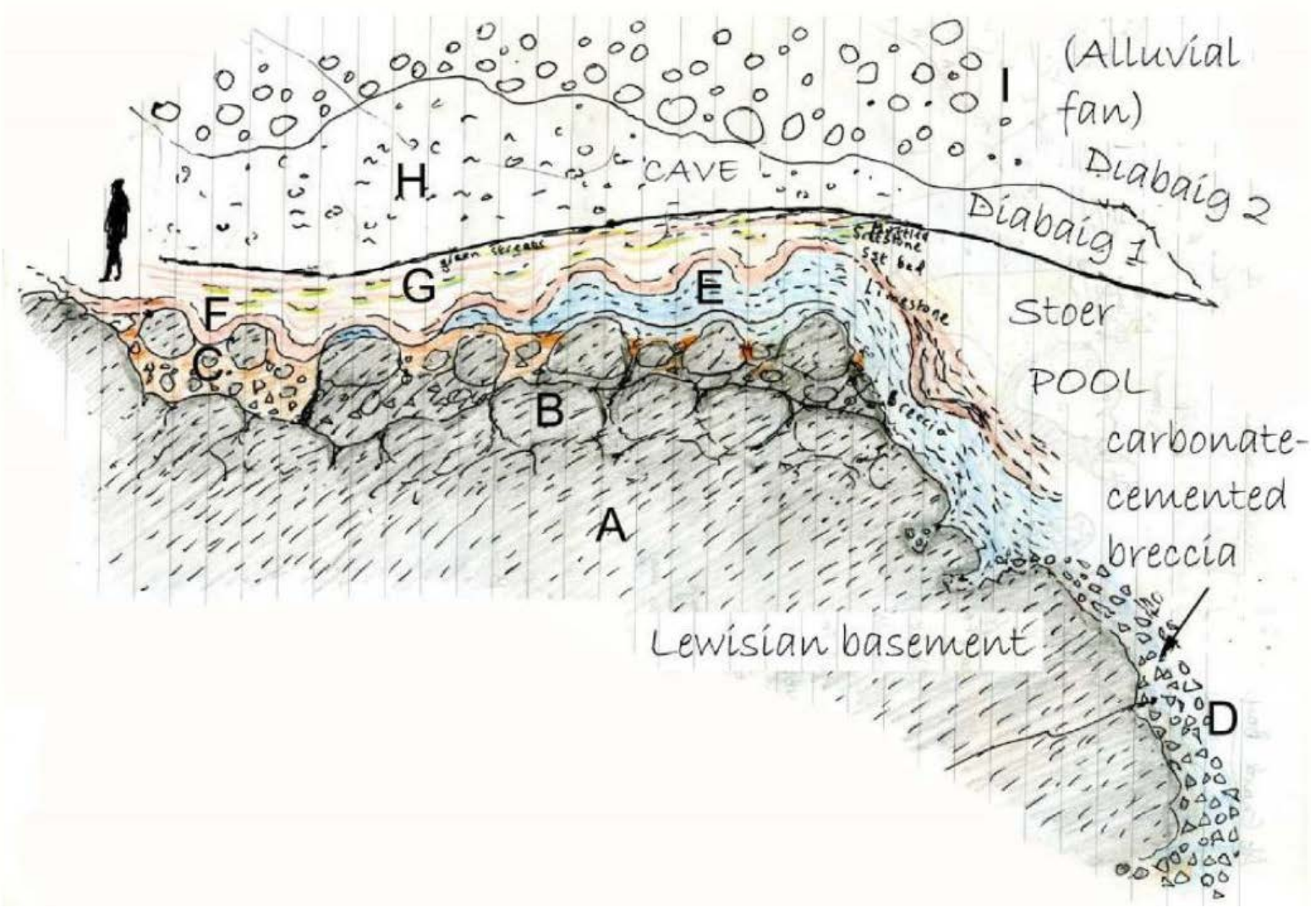

832

833

834

835

836

837

838

839

840

841

842

843

844

845

846

847

848

849

Fig. 6: cross-section of stratigraphy at Enard Bay (Fig. 1), showing Lewisian basement onlapped by silica-cemented and then carbonate-cemented breccias, Poll a Mhuilt Member limestones, siltstones and sandstones. These are truncated by conglomerates at the base of the Diabaig Formation. (A) Lewisian gneiss exposed and weathered during Stoer Group time to form a knoll like hill, ultimately forming an island within the Poll a'Mhuilt lake despoits; (B) Lewisian gness weathered into rounded boulders above the shoreline of the lake; (C) Lewisian gneiss weathered to form a regolith-like, silicacemented breccia at the base of overlap by Poll a' Mhuilt (Stoer Group) lake sediments; (D) Angular, cobble to pebble-sized clasts of Lewsisian gneiss locally cemented by carbonate; (E) Crinkly laminated carbonate layers within red sands, silts and muds of the Poll a' Mhuilt (Stoer Group) lake sediments, here locally draped around cobbles of Lewisian gneiss. This carbonate is suspected to have a partly microbial origin; (F) Thin tabular bed of red sandstone caps the carbonate and is draped (mainly from compaction) around cobbles of Lewisian gneiss. At this point, the Poll a' Mhuilt (Stoer Group) lake sediments have a less calcareous composition; (G) Mottled red and green siltstones and mudstones of the Poll a' Mhuilt (Stoer Group) lake sediments. The green may reflect reduction around spots of pyrite and/or organic matter; $(\mathrm{H})$ Pebbly red sandstones sediments inferred by Stewart (2002) to lie at the base the Diabaig Formation (Torridon Group), and here erosively overlying the Stoer Group. Possible alluvial fans and mass flow. They show localised green 

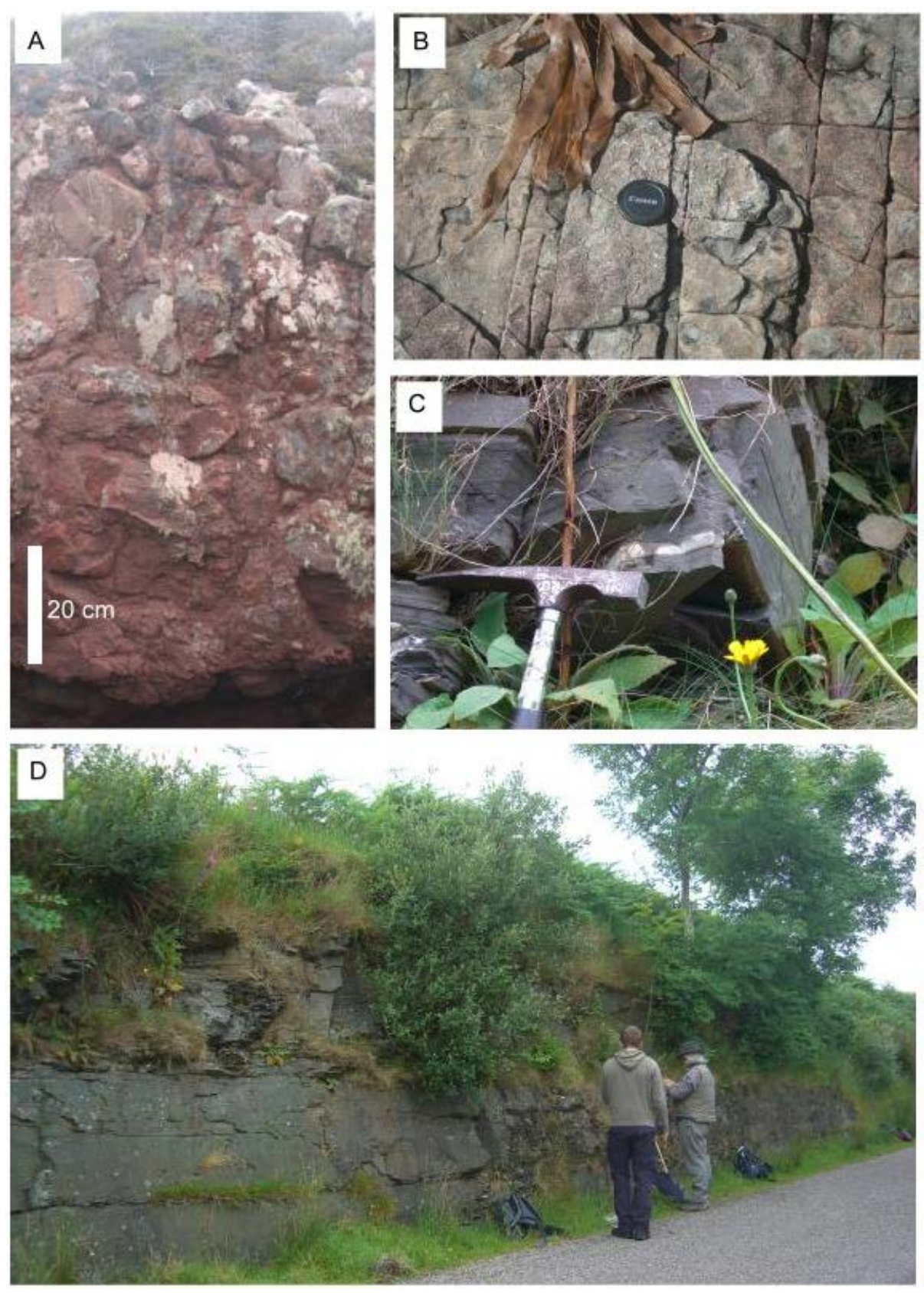

854 Fig. 7: Diabaig Formation in field photographs. A) Basal conglomerate at Enard Bay. B) White 855 phosphate (under lens cap) on a rippled bedding plane at Badenscallie. C) Lens of white phosphate in laminated shales at Badachro. D) Outcrop at Badachro, with Martin Brasier on the right. 

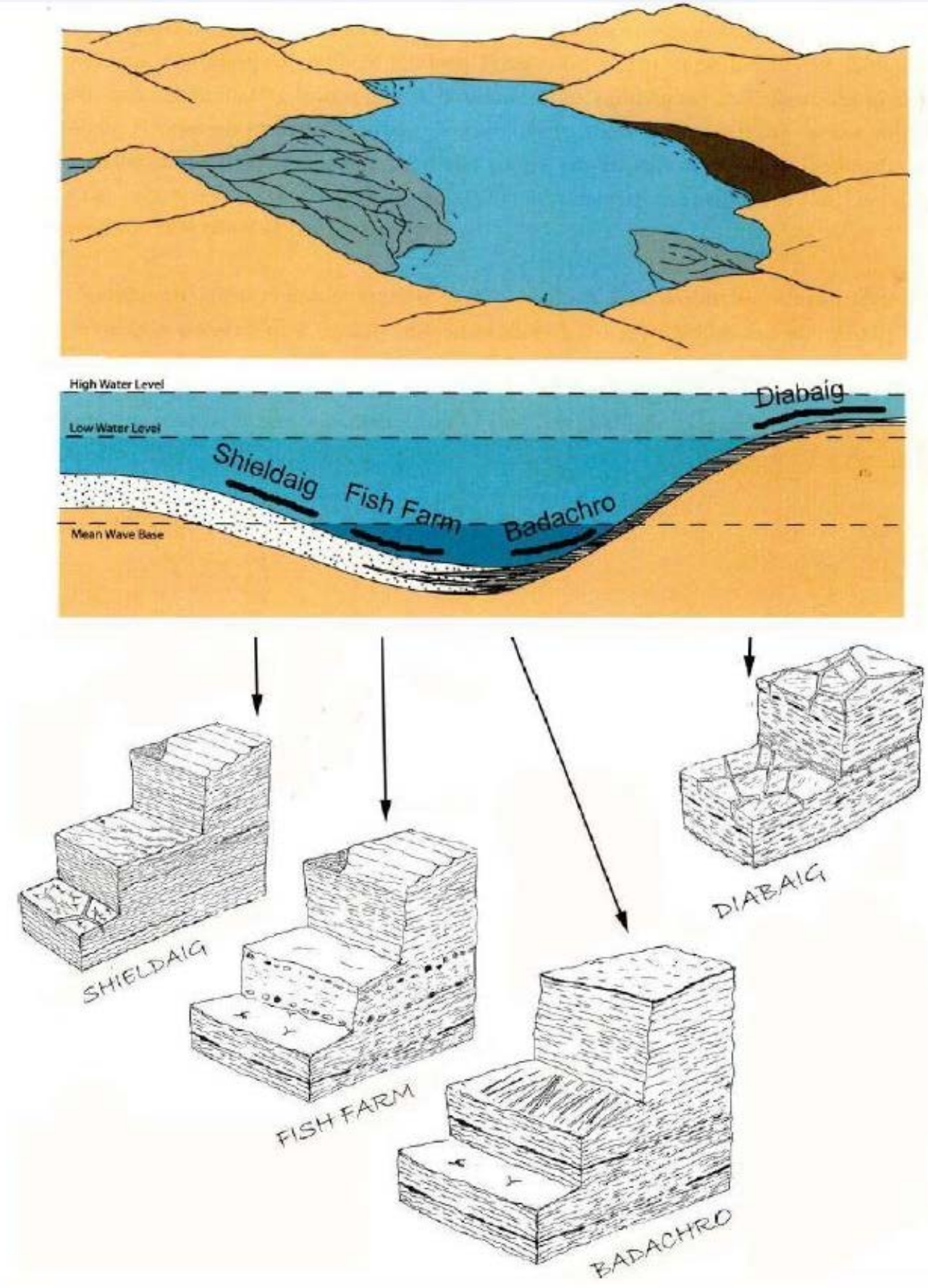

857

858 Fig. 8: Sedimentary features seen across parts of the Diabaig Lake from sandy shore (at left) or 859 muddy shore (at right) to deeper lake at Badachro; sketches from MDB field notes and Battison $860 \quad(2012)$ 

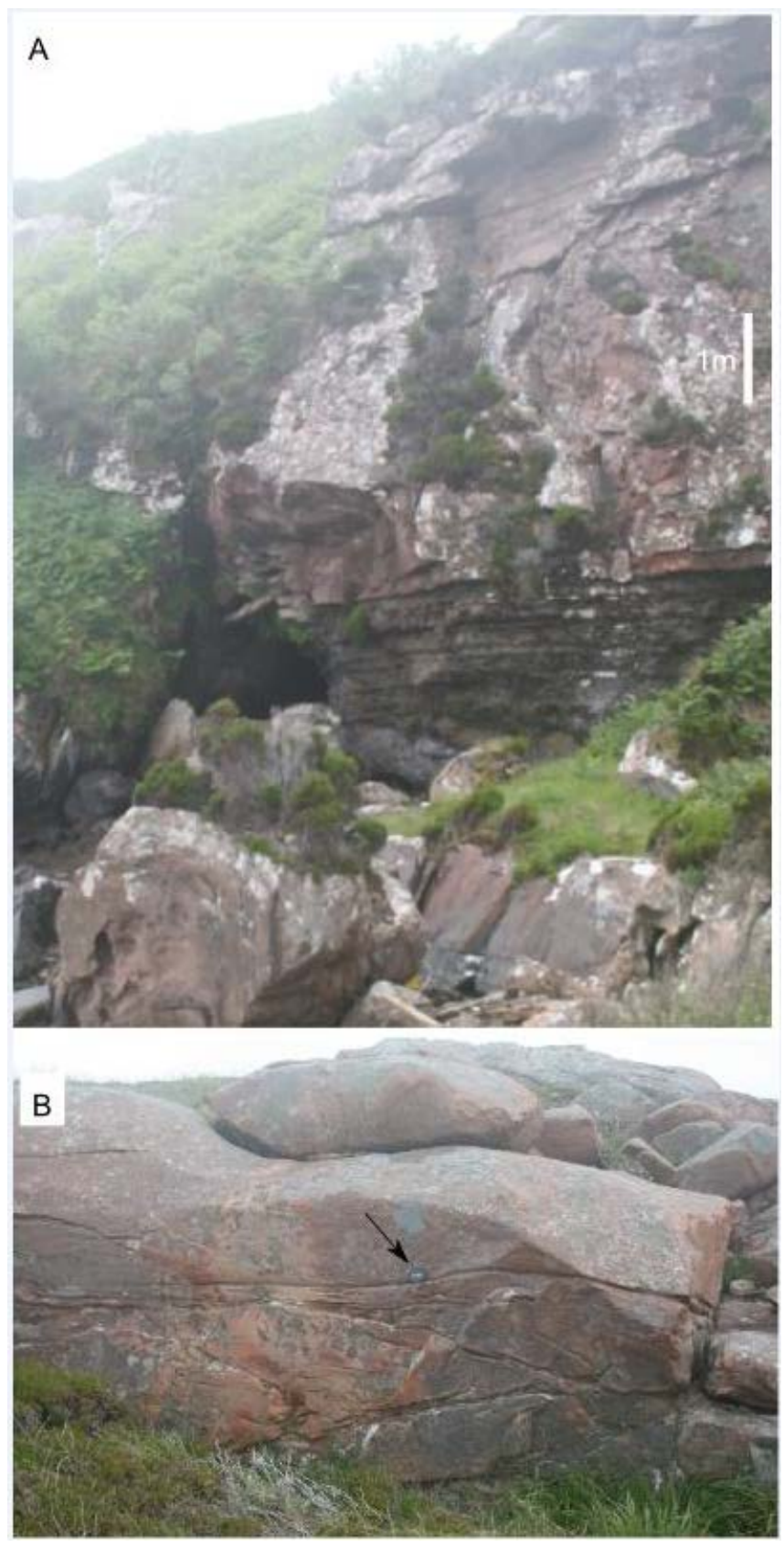

862 Fig. 9: Aultbea Formation outcrops on Tanera Beag, Summer Isles. A) Section showing the

863 microfossil-bearing shales below sandstones reported by Zhang et al. (1981). B) Red sandstones with

864 convolute bedding which is characteristic of the Aultbea and Applecross Formations, with lens cap 865 (arrowed) for scale. 


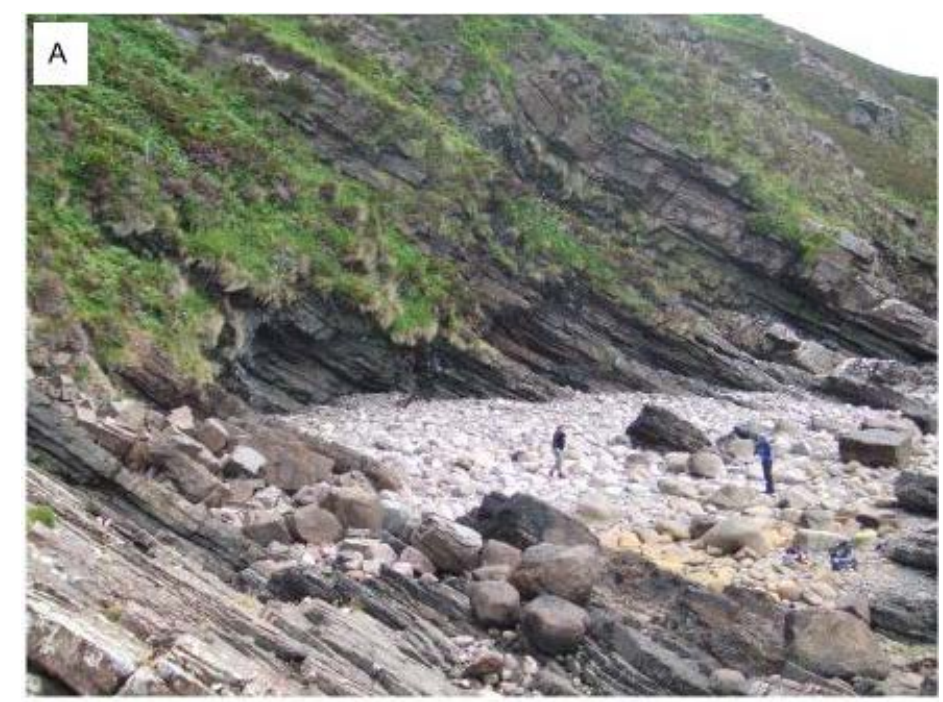

866

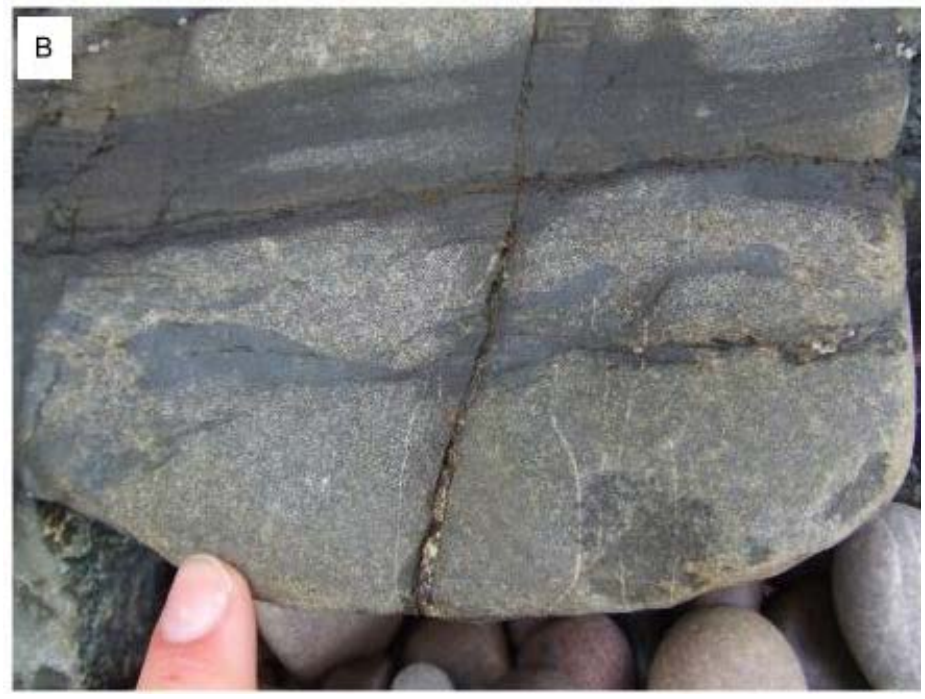

867 Fig. 10: Cailleach Head Formation at Cailleach Head. A) view of outcrop, showing cyclic

868 sedimentation of the Cailleach Head Formation (Torridon Group). B) close-up of phosphatic nodules

869 (black) within the Cailleach Head Formation. Photographs from Martin Brasier. 

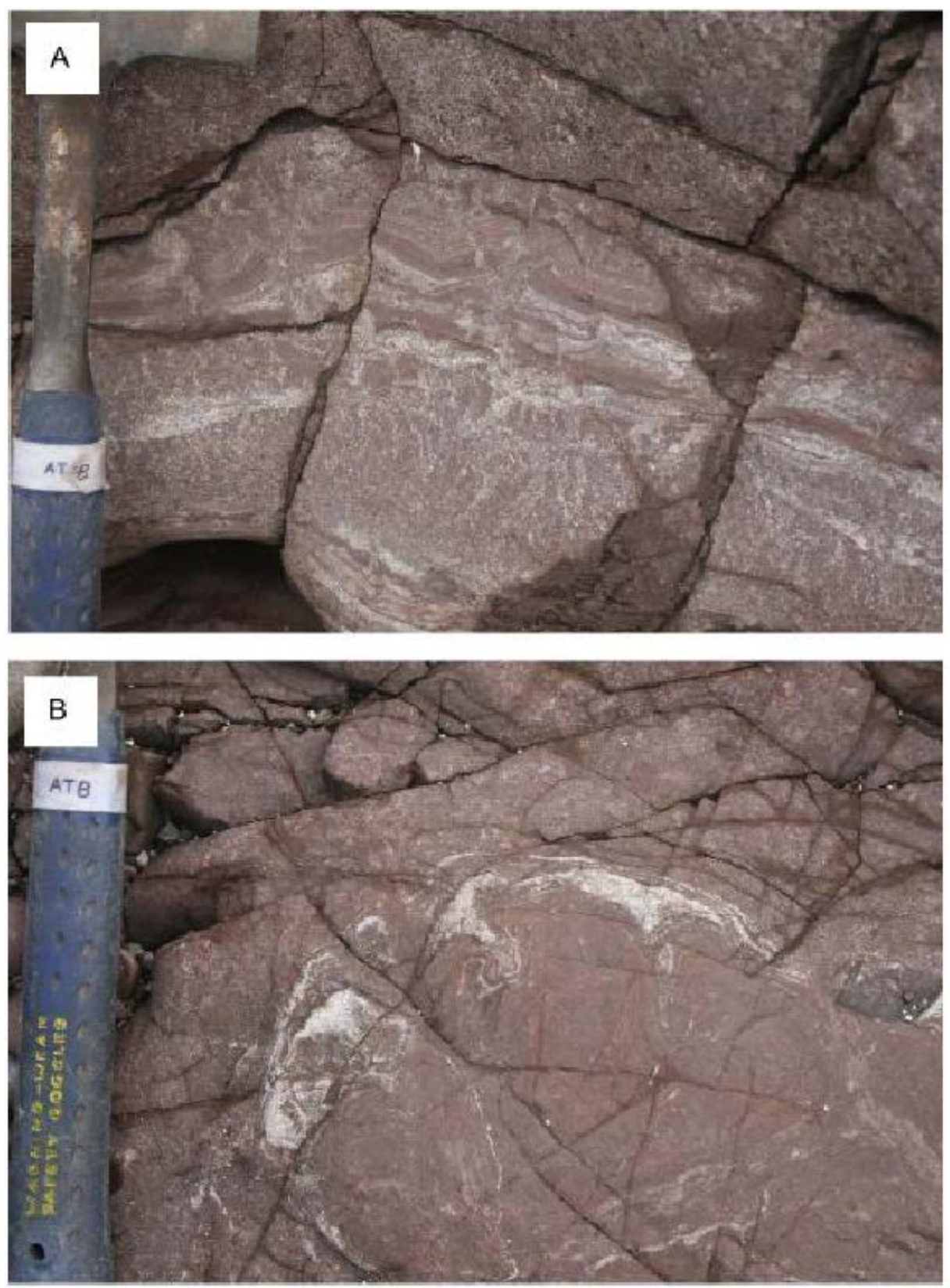

871 Fig. 11: Structures previously identified as 'stromatolites' in the Bay of Stoer Formation, A) in cross872 section and B) in plan view. Red is siliciclastic siltstone, white is calcite cement. The 'stromatolitic' 873 appearance is caused by abiotic processes involving syn-sedimentary buckling of mudstone layers 874 (driven by evaporation) with patterns picked out by interlayers of early (probably syn-sedimentary, 875 abiotic, evaporitic) calcite cement. 


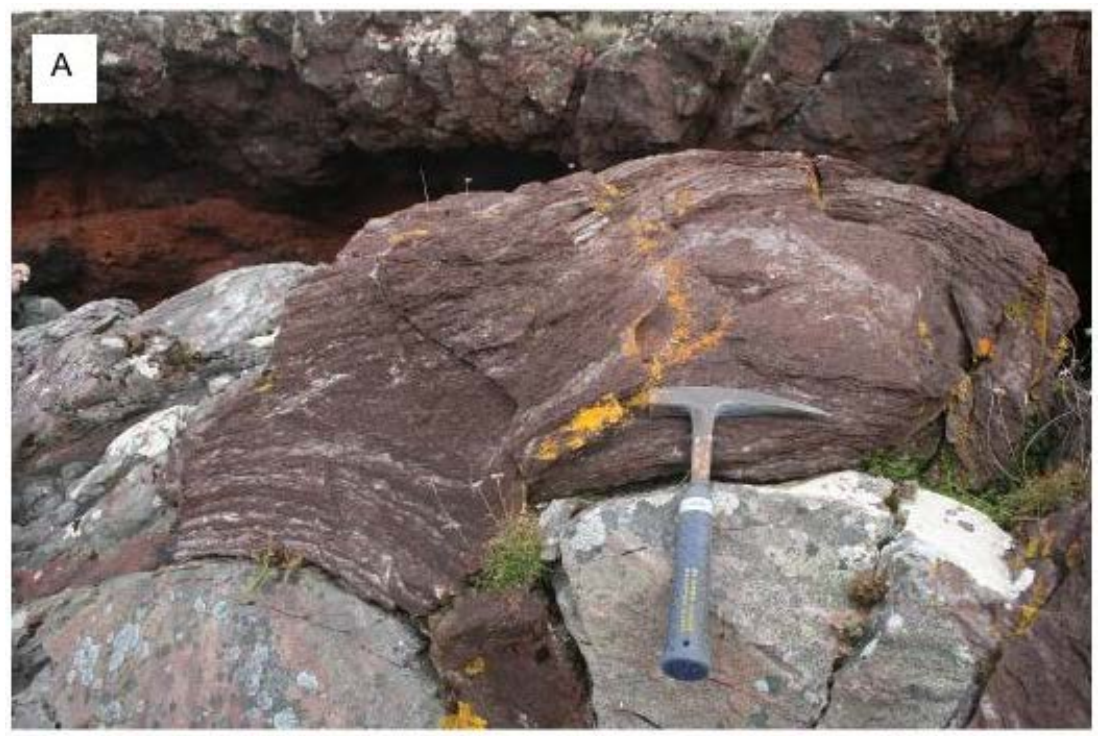

876

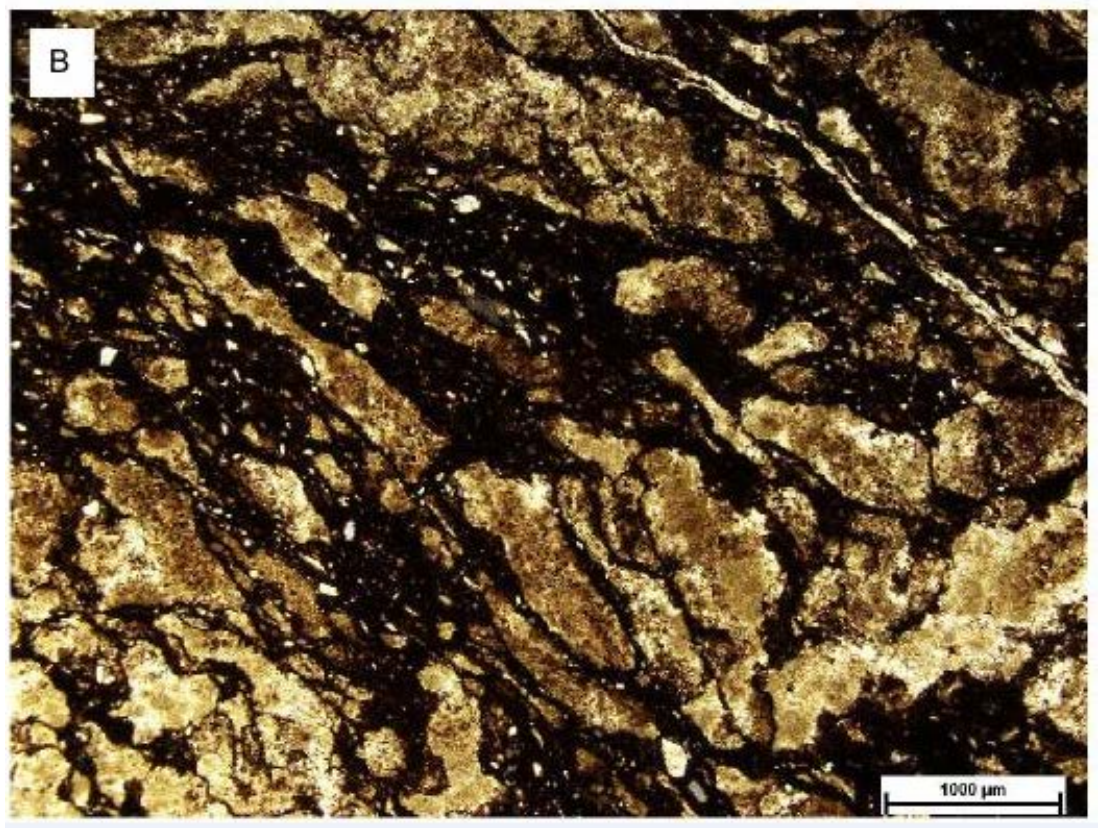

877 Fig. 12: Enard Bay stromatolites in outcrop (A) and thin-section (B). These stromatolites are draped 878 on gneiss boulders of the Lewisian unconformity (same surface as in Fig. 3). The stromatolites are 879 comprised of layers of red (siliciclastics) and white (calcite clasts) sediment. In thin-section the 880 siliciclastic layers are dark, and the calcite clasts are lighter coloured, $\mathrm{mm}$ sized, and elongated 881 parallel to layering. Diabaig Fm (basal Torridon Group) conglomerates are visible in the background 882 of (A), above the stromatolites. 

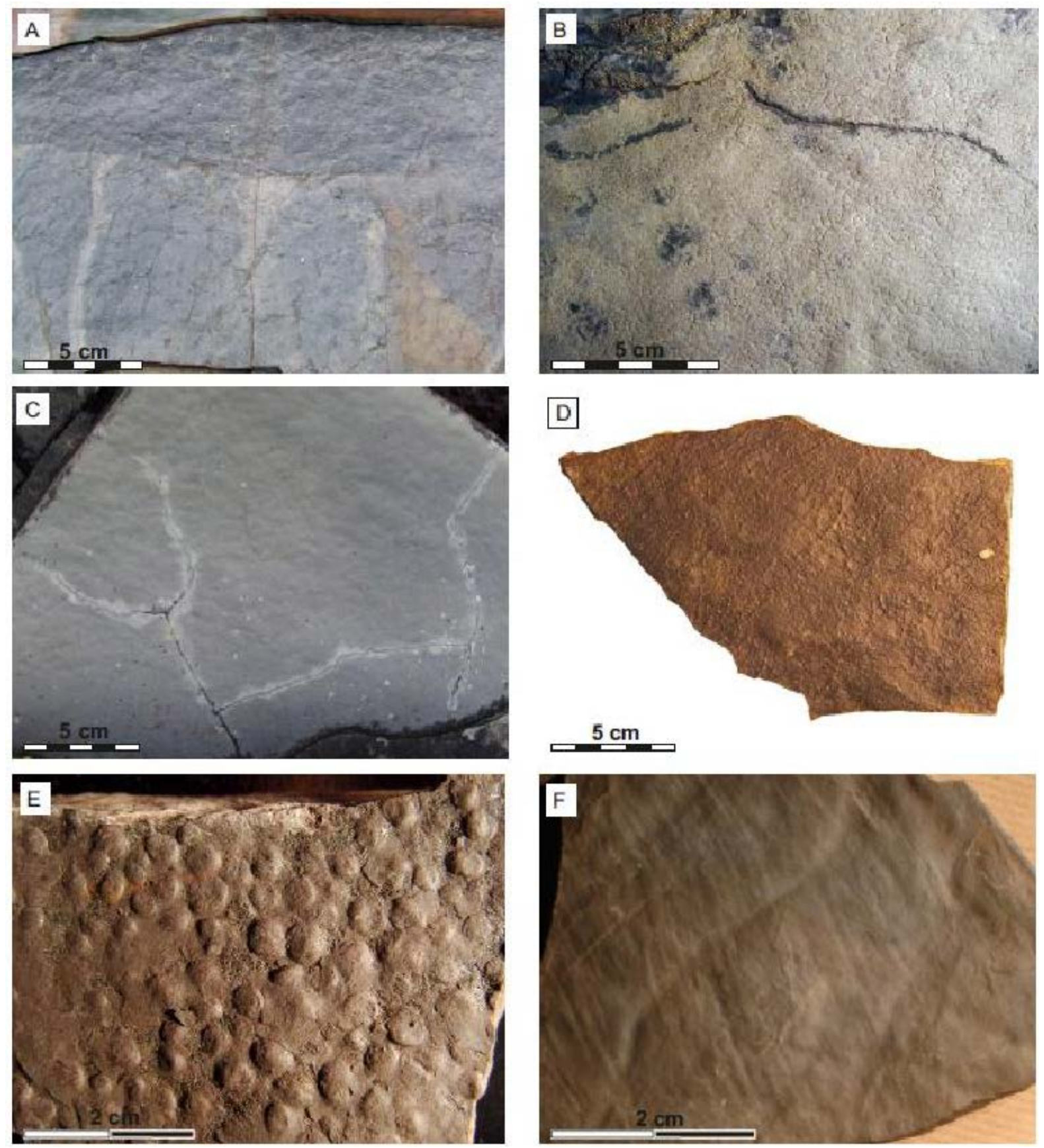

884 Fig. 13: Microbially Induced Sedimentary Structures (MISS sensu Noffke et al. 2001) from fine-

885 grained lacustrine facies of the Torridon Group, northwest Scotland. A) Polygonal reticulate mat

886 fabric consisting of raised, positive, irregular, polygonal ridges preserved on upper surface of fine-

887 grained siltstone-mudstone, Diabaig Formation, Diabaig. B) Similar fabric to that shown in (A) but

888 preserved in the opposite sense of relief, consisting of low-relief raised polygons separated by

889 shallow irregular grooves (cf. "elephant skin" texture). Sample is from the upper surface of a

890 siltstone bedding plane, Shieldaig North locality of Callow \& Brasier (2011). C) Elongate reticulate

891 fabric comparable to that shown in (A) but with a strong linear elongation of the polygons. The fabric consists of long positive-relief ridges separated by irregular cross-partitions between the ridges. 

circular discoidal structures on the upper surface of a red-coloured siltstone bedding plane, covered by a thin micaceous drape, Diabaig Formation, Brochel Castle, Raasay. The origin of these discoidal features remains unknown, although observations of deformed contacts between adjacent discoids and lack of amalgamation of the stuctures are difficult to explain as abiogenic features and may putative microbially-related structures known as "Arumberia".

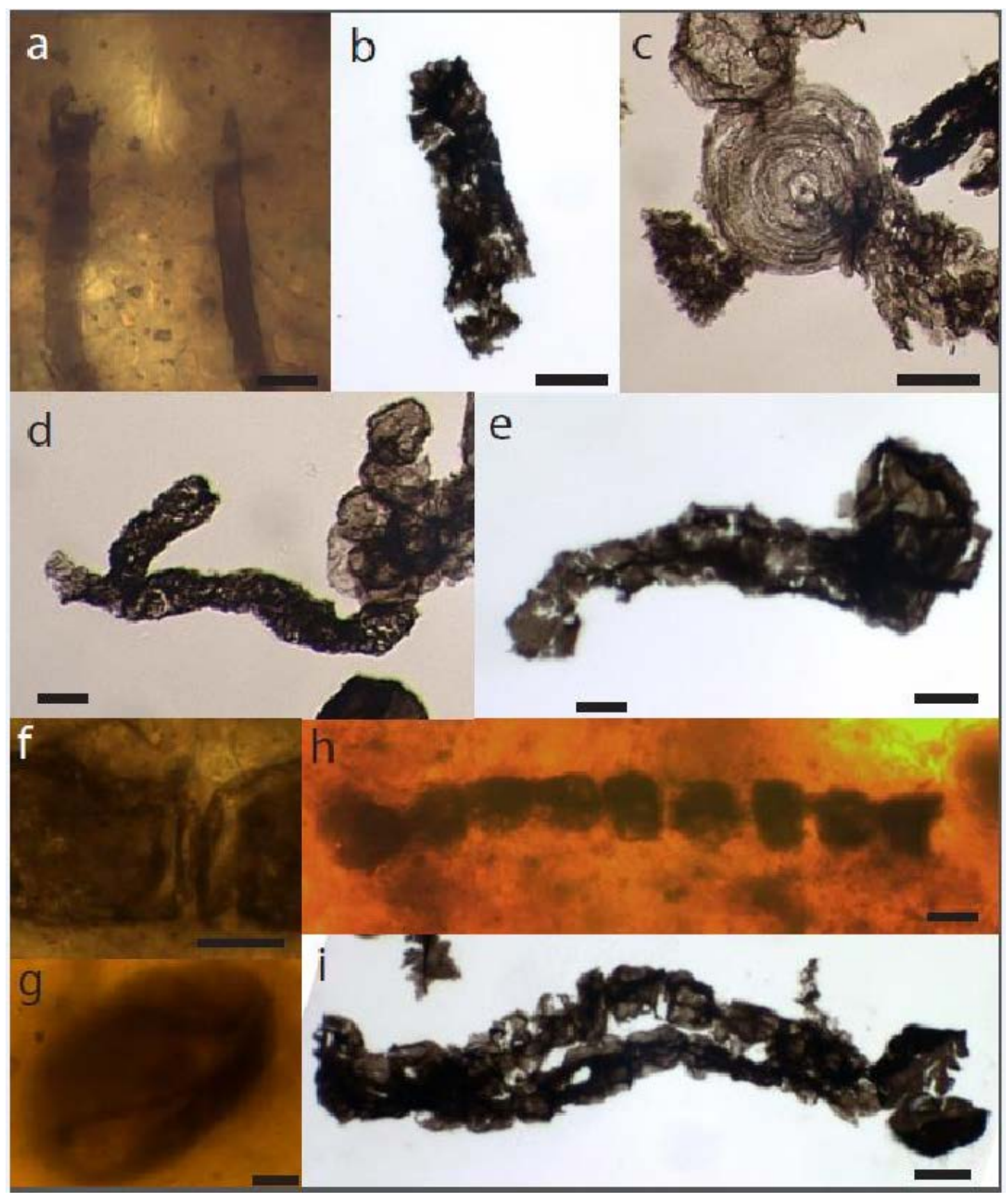


Fig. 14: Taxa from the Torridon Group, after Battison (2012). a) Siphonophycus inornatum. Sample

904 CAl-2a, phosphate from Cailleach Head, scale bar is $5 \mu \mathrm{m}$; b) Siphonophycus solidum. Sample T11-

905 106, macerate of shale from Lower Diabaig, scale bar is $20 \mu \mathrm{m}$; c) Volyniella (or Obruchevella?)

906 glomerata. Sample CAI-7mac, macerate of phosphate from Cailleach Head Formation at Cailleach

907 Head, scale bar is $15 \mu \mathrm{m}$; d) Archaeorestis unnamed species. Sample CAl-7mac, macerate of

908 phosphate from Cailleach Head Formation at Cailleach Head, scale bar is $10 \mu \mathrm{m}$; e) unnamed genus

909 and species A, asymmetric tubular structure with bulbous ends. Sample TOR08-45, macerate of

910 shale from Cailleach Head Formation at Cailleach Head, scale bar is $10 \mu \mathrm{m}$; f) Archaeoellipsoides

911 conjunctivus. Sample CAI-2f, phosphate from Cailleach Head Formation at Cailleach Head, scale bar

912 is $10 \mu \mathrm{m}$; g) Archaeoellipsoides obseus. Sample FLA-3a from Fladday, scale bar is $10 \mu \mathrm{m}$; h)

913 Veteronostocale unnamed species. Sample CAI-2e, phosphate from Cailleach Head Formation at

914 Cailleach Head, scale bar is $10 \mu \mathrm{m}$; i) Veteronostocale unnamed species. Sample TOR08-45, macerate

915 of Cailleach Head Formation shale from Cailleach Head, scale bar is $10 \mu \mathrm{m}$. 


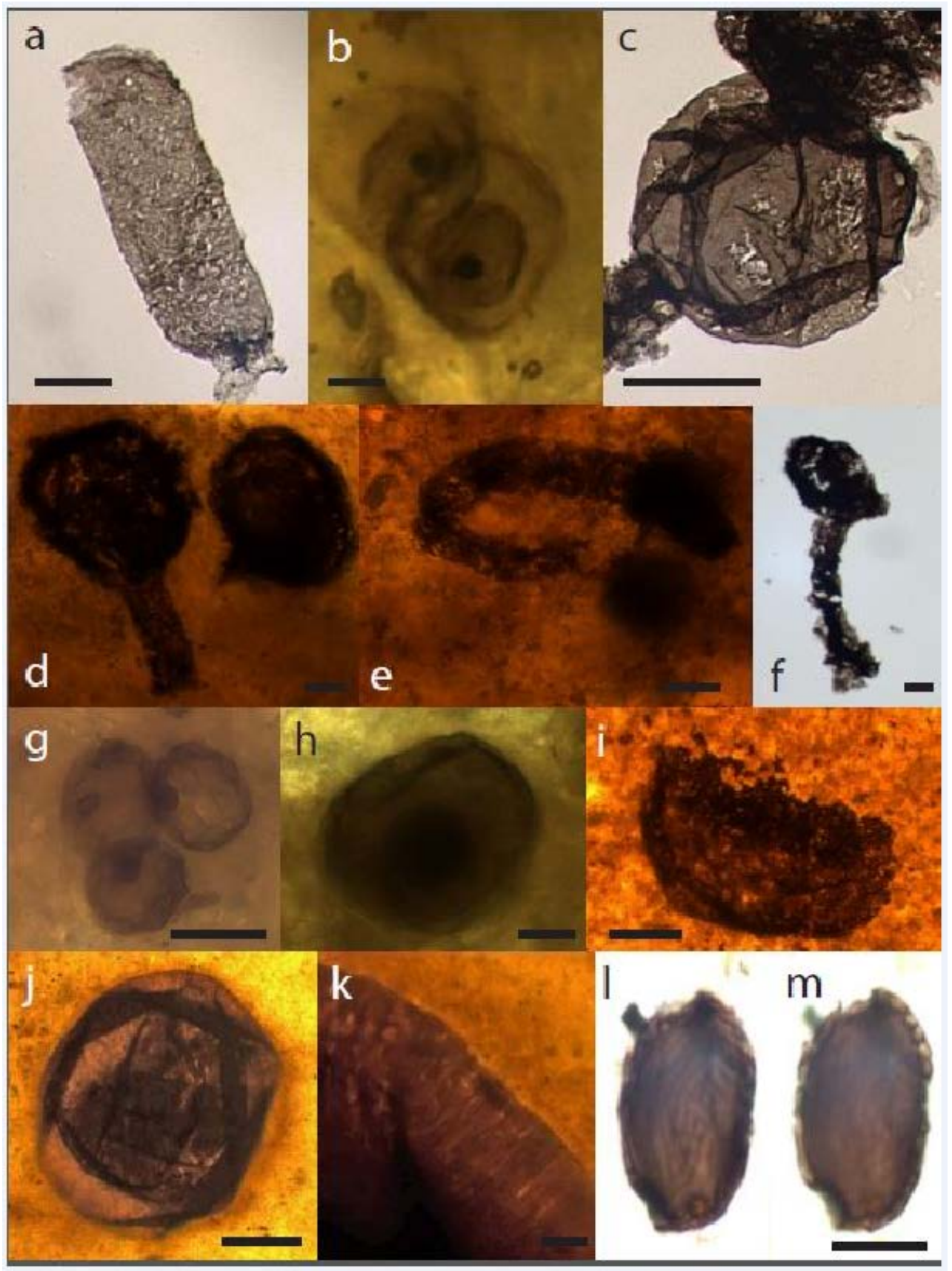

917 Fig. 15: Taxa from the Torridon Group, after Battison (2012). a) Archaeoellipsoides bactrophycus.

918 Sample CAI-7mac, macerate of phosphate from Cailleach Head Formation at Cailleach Head, scale 919 bar is $20 \mu \mathrm{m}$; b) Globophycus minor. Sample CAI-2f, phosphate from Cailleach Head Formation at 920 Cailleach Head, scale bar is $5 \mu \mathrm{m}$; c) Leiosphaeridia levia. Sample CAI-7mac, macerate of phosphate 921 from Cailleach Head Formation at Cailleach Head, scale bar is $30 \mu \mathrm{m}$; d) Germinosphaera unnamed species. Sample CAI-2e, phosphate from Cailleach Head Formation at Cailleach Head, scale bar is 10 $\mu \mathrm{m}$; e) Germinosphaera unnamed species. Sample CAI-2e, phosphate from Cailleach Head Formation at Cailleach Head, scale bar is $10 \mu \mathrm{m}$; f) Germinosphaera unnamed species. Sample DIA-13mac, macerate of phosphate from Diabaig Formation at Lower Diabaig, scale bar is $10 \mu \mathrm{m} ; \mathrm{g}$ ) 
Protosphaeridium parvulum. Sample CAI-2b, phosphate from Cailleach Head Formation at Cailleach

927 Head, scale bar is $10 \mu \mathrm{m}$; h) Pterospermopsimorpha pileiformis. Sample CAI-2f, phosphate from

928 Cailleach Head Formation at Cailleach Head, scale bar is $10 \mu \mathrm{m}$; i) Valeria unnamed species. Sample

929 FLA-3a, phosphate from Diabaig Formation at Fladday, scale bar is $100 \mu \mathrm{m}$; j) Valeria lophostriata.

930 Sample FLA-3a, phosphate from Diabaig Formation at Fladday, scale bar is $100 \mu \mathrm{m}$; $\mathrm{k}$ ) Striae on

931 surface of Valeria lophostriata in (j). Sample FLA-3a, phosphate from Diabaig Formation at Fladday,

932 scale bar is $10 \mu \mathrm{m}$; I) unnamed genus and species $B$, vesicle with complex cellular wall structure.

933 Sample FFA1-1.45a, phosphate from Diabaig Formation at North Sheildaig, scale bar is $10 \mu \mathrm{m} . \mathrm{m}$ )

934 same as for (I), scale bar is $10 \mu \mathrm{m}$.

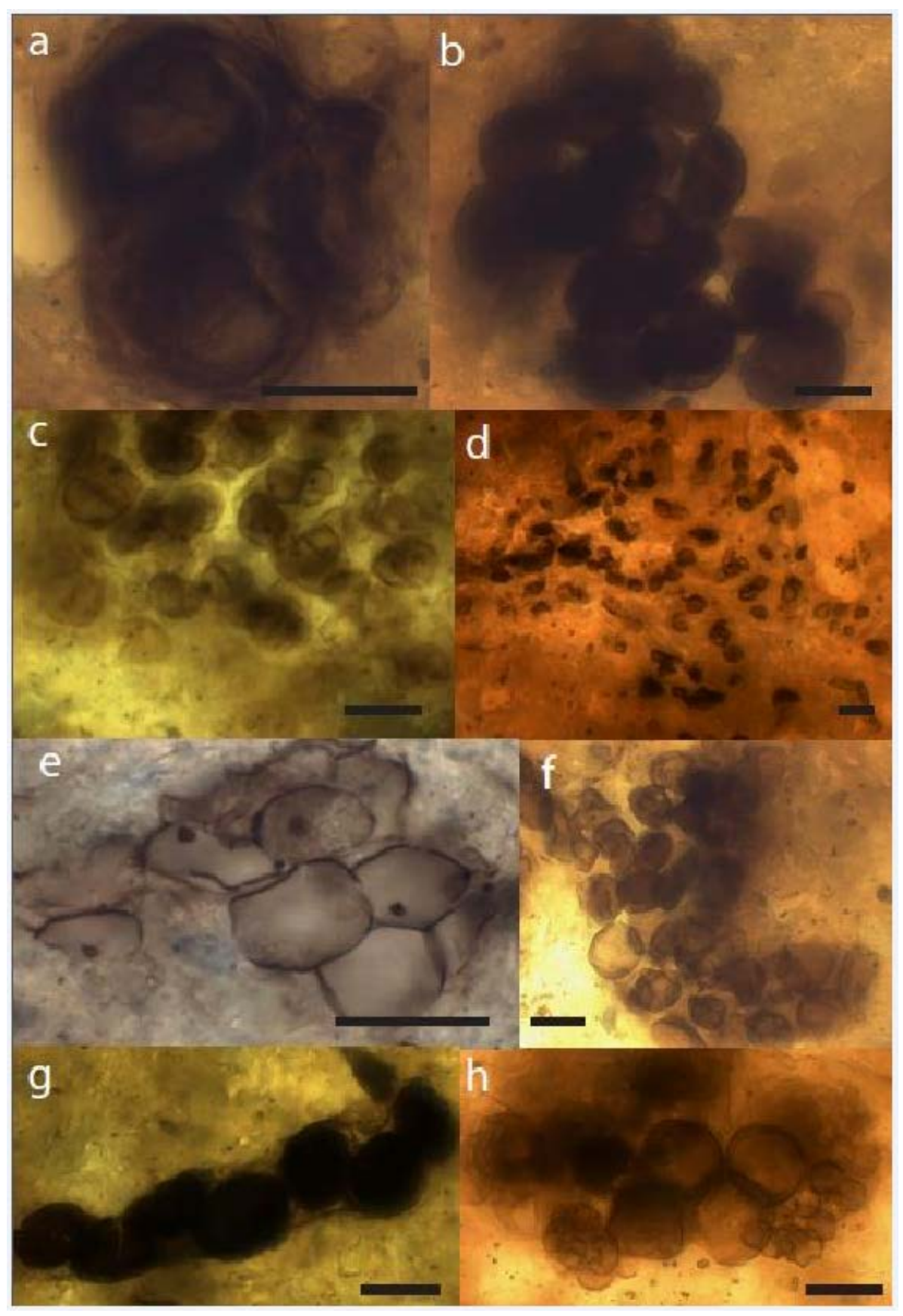


936 Fig. 16: Taxa from the Torridon Group, after Battison (2012). a) Gloeodiniopsis lamellose. Sample

937 CAl-2b, phosphate from Cailleach Head Formation at Cailleach Head, scale bar is $20 \mu \mathrm{m}$; b)

938 Maculosphaera kingstonensis. Sample CAI-2b, phosphate from Cailleach Head Formation at Cailleach

939 Head, scale bar is $10 \mu \mathrm{m}$; c) Myxococcoides distola. Sample CAI-7b, phosphate from Cailleach Head

940 Formation at Cailleach Head, scale bar is $15 \mu \mathrm{m}$; d) Myxococcoides kingii. Sample CAI-2c, phosphate

941 from Cailleach Head Formation at Cailleach Head, scale bar is $5 \mu \mathrm{m}$; e) Myxococcoides minor. Sample

942 FFA1-1.45a, phosphate from the Diabaig Formation at North Sheildaig, scale bar is $15 \mu \mathrm{m} ; \mathrm{f}$ )

943 Myxococcoides staphylidion. Sample CAI-2a, phosphate from Cailleach Head Formation at Cailleach

944 Head, scale bar is $10 \mu \mathrm{m}$; g) Unnamed form C, sheathed chain of dark vesicles. Sample CAI-7b,

945 phosphate from Cailleach Head Formation at Cailleach Head, scale bar is $20 \mu \mathrm{m}$; h) Unnamed form D,

946 bimodally sized vesicles in cluster. Sample CAI-2d, phosphate from Cailleach Head Formation at

947 Cailleach Head, scale bar is $20 \mu \mathrm{m}$.

948

949 